\title{
Corporate Social Responsibility and Firm Value:
}

\section{Disaggregating the effects on cash flow, risk and growth}

September 2013

Running Title: Corporate Social Responsibility and Firm Value

Alan Gregory, University of Exeter Business School, Xfi-Centre for Finance and Investment, Rennes Drive, Exeter, EX4 4ST, UK, E-mail: a.gregory@ex.ac.uk; Rajesh Tharyan, University of Exeter Business School, Xfi-Centre for Finance and Investment, Rennes Drive, Exeter, EX4 4ST, UK, E-mail: r.tharyan@exeter.ac.uk; Julie Whittaker, University of Exeter Business School, Department of Organisation Studies, Streatham Court, Rennes Drive, Exeter, EX4 4ST, UK, E-mail: j.m.whittaker@exeter.ac.uk .

The authors gratefully acknowledge the comments of Louis Ederington, Alex Edmans, Chitrou Fernando, Scott Linn, Vahap Uysal and Pradeep Yadav, together with seminar participants at the 2011 PRI Conference in Sigtuna, Sweden, the University of Bristol, the University of Oklahoma (Price College of Business), the University of Piraeus and the University of Swansea, together with the comments of two anonymous reviewers. We are also grateful to XiaoJuan Yan, PhD student at the University of Exeter, for her help in assembling the data for this paper.

Key words: corporate social responsibility, firm value, cost of capital, risk, growth 


\section{Corporate Social Responsibility and Firm Value:}

\section{Disaggregating the effects on cash flow, risk and growth}

This paper investigates the effect of corporate social responsibility (CSR) on firm value and seeks to identify the source of that value, by disaggregating the effects on forecasted profitability, long term growth and the cost of capital. The study explores the possible risk (reducing) effects of CSR and their implications for financial measures of performance. For individual dimensions of CSR, in general strengths are positively valued and concerns are negatively valued, although the effect is not universal across all dimensions of CSR. We show that these valuation effects are principally driven by CSR performance associated with better long run growth prospects, with an additional minor contribution made by a lower cost of equity capital. 


\section{Corporate Social Responsibility and Firm Value: Disaggregating the effects on cash flow, risk and growth}

\section{Introduction}

As many preceding papers have discussed, there is conflicting evidence on whether, and to what extent, corporate social responsibility (CSR) strategies (or the lack of them) affect a firm's financial performance (Margolis and Walsh, 2003; Orlitzky et al., 2003; Renneboog et al., 2008; van Beurden and Gossling, 2008; Margolis et al., 2009). There are many conceivable reasons as to why the evidence varies. These could relate to the context, e.g. the time, country, and industry, or differences in the dimensions of CSR observed. Moreover, disparities might be attributed to variation in methodological approaches. In the latter case, one reason for variation can be differences in the financial measures applied. Many studies have used accounting measures such as Return on Investment or Return on Equity (Orlitzky et al., 2003; Margolis et al., 2009) and whilst such measures have their use, they are backward looking and their objectivity and informational value can be questioned (Benston, 1982). Stock market measures, by contrast, are forward looking with expectations of future cash flows embedded within the stock price, and they are more relevant for considering the implications of CSR for investors.

The market measure most commonly used to consider the financial performance of CSR is stock market returns (Margolis et al., 2009). However such studies can produce misleading results because, in an efficient market, returns would be expected to reflect only changes in corporate social performance (CSP). If levels of CSP remain unchanged or if changes in CSP are relatively small for a firm for some time, then a returns based study can give the wrong impression that CSP does not affect financial performance. This is pertinent given some evidence to suggest that CSP measures are sticky. For example, Gregory and Whittaker (forthcoming) note that for any given year there is a significantly high correlation between the current CSP and lagged CSP, and that these correlations are higher for larger firms. Furthermore, even when returns based studies indicate some financial impact from CSR strategies, care needs to be taken in the interpretation of the results, following recent studies by Sharfman and Fernando (2008) and El Ghoul et al. (2011) which suggest that firms with a high level of CSP may enjoy a lower cost of capital. Their findings raise questions regarding the implications of high CSR firms generating lower returns over the long run. Is such an 
effect because the firms were poorly managed, or rather, is it the case that realised low returns are the consequence of CSR strategies lowering the ex ante cost of capital?

Specifically, the long run returns to firms with high CSR, could be lower for a given expected future cash flow simply because they are subject to less market risk, and not the consequence of poor management. Therefore, if CSR does lower a firm's cost of capital, focusing solely on returns to indicate the financial impact of CSR might be misleading. To understand the total financial implications of CSP it is therefore necessary for attention to be given to both stock returns and firm value. Relatively few studies have based their estimations on firm value but recent studies that have used this concept (Guenster et al., 2011; Jo and Harjoto, 2011; Kim and Statman, 2012; Gregory and Whittaker (forthcoming)) find evidence of CSR indicators being positively related to firm value. In this paper we extend this literature with an investigation of the means by which CSR strategies might impact on value.

A focus on firm value is highly relevant to investors, but it is also pertinent to know more about the source of that value, and specifically, the extent to which it emanates from its two main components, expected future cash flows and the cost of capital. Using the model presented in Gregory and Whittaker (forthcoming), which offers a means of testing the relationship between CSR indicators and firm value in a more theoretically robust manner than the employment of Tobin's Q, we attempt to separate the effect of each on firm value, and simultaneously contribute to the debate on how CSR impacts on risk. We draw on literature from the resource-based perspective and stakeholder theory to embark on disentangling how CSR strategies might affect cash flows (including firm-specific risk) and cost of capital (and thereby systematic risk). In addition, given that high CSR firms may incur higher initial costs when they invest in CSR, but perform better in the longer term than low CSR firms (Russo and Fouts, 1997; Barnett, 2007; Sharfman and Fernando, 2008), we examine expected (forecasted) earnings to identify differences in expected (forecasted) profitability, together with long term growth expectations, and analyse their bearing on firm value. We also investigate realised returns as a way of identifying the way that risk exposures vary with CSR strategies, and further employ the Easton et al. (2002) mode as a robustness check on the relative contribution of growth and cost of capital effects in explaining the way value varies with CSP. Furthermore, we extend the work of Gregory and Whittaker by examining the valuation of CSR strengths and weaknesses separately, and by 
categorizing firms according to the "purity" of their commitment to CSR using the classification developed in Fernando et al. (2010).

Both in our conceptualisation of CSR as based in stakeholder theory and in the specification of the theoretical framework and methodology we employ, there is an implicit assumption that CSR has a causal effect (which could be positive or negative) on financial performance. We note that there have been objections within the literature to assumptions that a positive correlation between CSR and CFP is a result of this causal relation. For example Preston and O'Bannon (1997) and Waddock and Graves (1997) have suggested that causation could lie in the opposite direction, with the availability of slack (financial) resources determining the amount of spending on CSR. While this line of enquiry is open to further investigation (and indeed there have been recent attempts to examine this, for example, Garcia-Castro, et al. (2010)), we suggest that it has become less relevant as CSR has become more associated with strategies of stakeholder engagement (as opposed to discretionary philanthropy) and with evidence that it is the significant and perpetual levels of investment in stakeholder engagement that are associated with superior financial performance (Barnett and Salomon, 2012; Choi and Wang, 2009; Godfrey et al., 2009; Kim and Statman, 2012; Wang and Choi, 2013). Therefore, it seems less likely that short term financial slack can drive a long term CSR commitment. Furthermore, Kim and Statman (2012) and Gregory and Whittaker (forthcoming) show that changes in CSP lead to subsequent changes in value, and that firms appear to be acting in the best long run interests of the shareholders when changing the level of engagement with CSR. Recent research by Flammer (2013) uses exogenous variation in CSR in the form of adoption of close-call shareholder proposals on CSR and finds that CSRrelated shareholder proposals leads to superior financial performance. This finding, under conditions where causality is certain, also lends support to our basic assumption that CSP is more likely to be the driver of valuation effects than the result of it.

\section{Theoretical framework and hypotheses}

Our theoretical starting point is the rational market valuation of the firm. Fundamentally, the value of any firm is the present value of its future cash flows, discounted at the appropriate cost of capital, such that the value of the firm's equity ${ }^{1}$ is given by:

\footnotetext{
${ }^{1}$ Firms can be valued in various ways, for example, at the enterprise level (that is to say, the combined value of the firm's debt and equity) or at the equity or shareholder level (which involves valuing firm level cash flows at the equity cost of capital), but properly calculated the results are always equivalent (Lundholm and O'Keefe, 2001). In this paper, the equity level is the focus, purely because the models employed in this paper have originated at this level.
} 


$$
\mathrm{V}_{\mathrm{t}}=\sum_{\mathrm{t}=1}^{\mathrm{t}=\infty} \frac{\mathrm{C}_{\mathrm{t}}}{\left(1+\mathrm{r}_{\mathrm{e}}\right)^{\tau}}
$$

Where $C_{t}$ is the expected cash flow in year $t$, and $r_{e}$, the rate of return required by the shareholders. Since investors and stock market analysts typically think, and forecast, in terms of expected future profits rather than cash flows, it is helpful to convert (1) into a valuation model based on expected profits, $x_{t}$, and accounting book values, $b_{t}$, rather than expected cash flows (Peasnell, 1982; Ohlson, 1995; Lundholm and O'Keefe, 2001). This model is based upon the economic notion of 'normal' profit rates, which would be the required return on the opening value of the assets, or $r_{e} \times b_{t-1}$. 'Abnormal profits', or 'residual income' will then be $x_{t}^{a}=x_{t}-r_{e} \times b_{t-1}$ and the firm will be worth the present value of its future residual income plus its opening asset value. So (1) can be restated as:

$$
\mathrm{V}_{\mathrm{t}}=\mathrm{b}_{\mathrm{t}}+\sum_{\tau=\mathrm{t}+1}^{\tau=\infty} \frac{\mathrm{x}_{\tau}^{\mathrm{a}}}{\left(1+\mathrm{r}_{\mathrm{e}}\right)^{\tau}}
$$

Our objective is to examine the difference CSR makes to both cash flow expectations, and cost of capital expectations. This involves ascertaining how the cost of equity varies with risk, and establishing the distinction between firm-specific risk and systematic risk.

Systematic, or market, risk is typically macro-economic in nature. Examples include economic growth rate shocks, interest rate shocks, oil price shocks and inflation shocks, all of which affect the majority of stocks, though some stocks are more exposed to this type of risk than others. Capital goods manufacturers, highly leveraged firms and financial stocks tend to be more exposed to adverse macro-economic conditions, while typically utilities and supermarkets have a relatively low exposure. In contrast to systematic risk, firm-specific risk is particular to a firm. The relevance of the distinction between the two types of risk is that, since an investor can diversify away firm-specific risk, it is solely the systematic risk that is a determinant of the required rate of return, and thereby the cost of capital. Consider two recent disasters. The Deepwater Horizon accident involving BP was firm-specific, and a diversified investor would experience little financial loss, whilst the effect of the collapse of Lehman brothers was economy wide, resulting in unavoidable losses. ${ }^{2}$ This systematic risk could not be circumvented through diversification across companies.

\footnotetext{
2 The clean-up and compensation costs to BP of the Deepwater Horizon accident have been estimated at up to \$37bn (Financial Times 26/2/12). This cash flow effect resulting from firm-specific risk, however unpalatable it may seem, can be diversified away by shareholders. For instance, at the worst point in the spill disaster, BP's
} 
In the Capital Asset Pricing Model (CAPM), commonly used in strategic management research (Ruefli et al.1999), the relationship between systematic risk and the cost of capital, $r_{e}$, is a function of the risk free rate, $r_{f}$, the expected return on the market as a whole, $r_{m}$, and the stock's beta, $\beta_{e}$. Beta captures the volatility of the stock in relation to the market and so indicates the degree of exposure to systematic risk.

$$
\mathrm{r}_{\mathrm{e}}=\mathrm{r}_{\mathrm{f}}+\beta_{\mathrm{e}}\left(\mathrm{r}_{\mathrm{m}}-\mathrm{r}_{\mathrm{f}}\right)
$$

The CAPM assumes that there is only one systematic risk factor, the exposure to which is captured by the beta $\left(\beta_{e}\right)$. However, there is considerable debate regarding the most appropriate asset pricing model and alternative models to the basic CAPM in (3) have been suggested, such as conditional CAPMs, the Fama-French three factor (1993) model, the Carhart (1997) four factor model and Arbitrage Pricing Theory models. Significantly, all of these models share the same fundamental hypothesis that with diversified portfolios, only systematic risk affects expected returns. From the point of view of the shareholders, $r_{e}$, is the required rate of return for a particular firm given its exposure to systematic risk factors. From the firm's point of view, $r_{e}$ is their cost of equity capital. It follows that the higher the systematic risk exposure, the higher the expected return to compensate for the risk.

None of this implies that markets are indifferent to firm-specific risk. Instead, rather than being reflected in the expected cost of capital, firm-specific risks are rendered in expected future cash flows. Consequently, the firm-specific risk of any CSR impacts will show up as positive or negative impacts in the expected cash flows, but will not influence the expected cost of equity capital. Overall, it follows that firm value is enhanced by expectations of higher growth in cash flows, lower probability of cash flow shocks, and lower exposure to adverse macro-economic conditions resulting in low systematic risk. An example of a firm adopting policies that reduce its carbon footprint through improved energy efficiency provides a hypothetical case that illustrates all three possible effects on firm value. More efficient use of energy not only reduces costs and so improves cash flow, but also gives the firm a lower exposure to energy prices. Since energy prices impact upon the economy, we

shares roughly halved in value. However, a well-diversified investor with just $1 \%$ of her portfolio in BP's stocks would have suffered a loss of around $0.5 \%$ on such a portfolio. Contrast this situation with the collapse of Lehman Brothers. On the single day that this event occurred, the US market as a whole fell by $4.71 \%$. Therefore, even if the investor was perfectly diversified across the five hundred stocks that comprise the S\&P 500 index, in just one day she would have suffered a near 5\% fall in her wealth. Of course, international diversification helps, but all major markets fell when Lehman's filed for bankruptcy. 
might reasonably expect our low carbon firm to have a lower beta as a consequence of this strategy. In addition, if this strategy finds favour with consumers of its products, it might also enjoy higher cash flows as the result of its policies. These cash flow effects could show up either in the form of higher profitability immediately, or in the form of superior long run growth prospects as more consumers switch to the firm's products. The net effect will be that both numerator and denominator in (1) and (2) will change. Further, such a strategy might also diminish firm-specific risk by reducing the company's vulnerability to the threat of any government introduction of carbon pricing to its industry. Once again this would change the numerator as expected cash flows would be increased by the reduction in firm-specific risk. This insight is at the heart of our approach to examining the means by which CSR impacts upon firm value.

While much has been written from the resource-based view and stakeholder perspectives on how CSR strategies might influence firm performance, we need to specifically make a distinction between the relevance of CSR for cash flows, particularly over a longer time period, and for the cost of capital. The resource-based view of the firm (Barney, 1991) implies that firms are rewarded with a higher stock price if they achieve and sustain a competitive advantage. To attain this, firms must have value creating resources that are rare, and difficult to replicate and substitute. Intangible resources, such as intellectual capital, organizational skills, corporate culture and reputation, are understood to be important in achieving a competitive advantage and CSR is considered to be influential in this respect (Branco and Rodrigues, 2006, Surroca et al. 2010). Hart (1995) proposes the 'naturalresource-based view' and identifies the potential for firms of gaining long term advantage through developing complex cross-functional teams to address environmental concerns. Russo and Fouts (1997) and Aragón-Correa and Sharma (2003) elaborate on the intangible organizational skills acquired by going beyond legal compliance on environmental matters. Other literature focuses on CSR strategy employed through stakeholder engagement. For example, Jones (1995) suggests that there are benefits to firms from developing stakeholder trust through reduced transaction costs, and Hillman and Keim (2001) find evidence that transforming relationships with primary stakeholders from transactional to relational, could enhance competitive advantage.

As previously noted, CSR strategies can also improve cash flows by mitigating firm-specific risk. For example, pollution prevention policies reduce the risk of fines or clean up costs, and 
good employee relations can reduce the risk of labour disruption. Godfrey et al. (2009) have expanded the argument that CSR reduces firm-specific risk, by providing evidence that good relationships with stakeholders build goodwill, and thereby reduce the cash flow shock when a negative event transpires. For instance, should an environmental accident or a product safety concern occur, the likelihood of consumer boycotts and other negative cash flow effects is lessened as a result of having moral capital. Choi and Wang (2009) argue that positive stakeholder relations not only help a company gain a competitive advantage, but sustain an advantage over the long term. Their case is based on good stakeholder relations facilitating the development of new capabilities, thereby reducing the likelihood of core competences becoming core rigidities, and thus enabling a company to move out of disadvantageous business circumstances, and reduce firm-specific risk.

From an instrumental standpoint, engaging in a CSR strategy is a form of investment, entailing initial costs for future financial benefits (Branco and Rodrigues, 2006). It may be that the impact on the long run future cash flows is positive, but short run cash flows are adversely affected. Russo and Fouts (1997) draw attention to the short run financial risk of investing in pollution prevention technology in the expectation of long run rewards. Barnett (2007) gives emphasis to the time required to build effective stakeholder relationships, arguing that only those firms with a real commitment to CSR activity are likely to realize the long term benefits of such investment. Consequently, only high levels of investment in CSR yield net benefits, with a lower degree of commitment failing to generate benefits greater than costs, resulting in a U-shaped relationship between CSR and financial performance. Barnett and Salomon (2012) provide evidence using accounting data (Return on Assets and Net Income) to support this hypothesis. The implication for firm valuation is that although there may be a short term negative impact on profitability, if investors are able to infer which firms are making a serious commitment to a CSR agenda and value those firms accordingly, then such firms will be rewarded by higher valuations despite negative short term profits. This leads to our first two hypotheses:

Hypothesis 1. CSR strengths add to value while CSR weaknesses detract from value. Hypothesis 2. Higher CSR firms will have higher near term profitability or higher medium to long term growth in earnings and residual income. 
Studies considering the effect of CSR on firm risk have mainly concentrated on the reduction of firm-specific risk rather than on how CSR affects the firm's exposure to systematic risk. Certainly the link between CSR strategies and firm-specific risk is more direct than the link between CSR strategies and systematic risk. McGuire et al. (1988, p.857) find weak evidence of a negative association between CSR and systematic risk, and state their position that 'The impact of social responsibility on measures of a firm's systematic risk may, however, be minimal, since most events affecting a firm's level of social responsibility do not systematically affect all other firms in the marketplace'. Perrini et al. (2011) recently reviewed how CSP might impact on financial performance but although noting the risk mitigating effects of CSR, did not deconstruct them into firm-specific and systematic risk effects.

Nevertheless, in recent years there has been greater interest in whether CSR might affect systematic risk and thereby the firm's cost of capital. Sharfman and Fernando (2008), focusing on environmental strategy, show for their sample that a firms beta is a declining function of its degree of environmental risk management, suggesting that firms that invest in this form of risk management enjoy a lower cost of capital. El Ghoul et al. (2011) adopt a different approach to determine the implied cost of capital, and follow Hong and Kacperczyk (2009) in applying the theoretical work of Heinkel et al. (2001) that proposes that firmspecific risk might also be an influence on the cost of capital. Heinkel et al.'s argument is based on the conjecture that if a sufficient number of principled investors do not invest in polluting firms, the reduced investor base raises the cost of capital because the opportunities for diversifying risk are diminished. Hong and Kacperczyk (2009) focus on firms in certain 'sin' industries (alcohol, tobacco, and gaming) that are excluded from the portfolios of some principled investors. However, Hillman and Keim (2001) view the exclusion of such industries as 'social issue participation' issues, outside the normal domain of CSR, and it remains an empirically open question as to whether sufficient investors have been deterred from investing in particular firms with low CSR, as opposed to avoiding specific industries as in the case of Hong and Kacperczyk (2009).

An alternative, and more general, approach to considering the theoretical possibility of CSR having an impact on the cost of capital is offered by acknowledging that an individual stock's beta is partly determined by the total risk of a stock's return. Therefore it is shaped by factors 
that also influence firm-specific risk (Peavy, 1984). ${ }^{3}$ Lubatakin and Chatterjee (1994, p. 113) have argued that 'some factors that have traditionally been ascribed to one component of corporate stock return risk also influence the other components'. They employ an example of a firm installing a new technology, which establishes a market entry barrier that will ensure regular cash flows. Although this is a firm-specific risk reducing effect, it could reduce systematic risk as well by putting the firm in a more powerful position to determine output and input prices during macro-economic disturbances. In line with this, Albuquerque et al. (2012) (following the work of Luo and Bhattacharya, 2009), suggest that good customer relations can reduce the elasticity of demand, therefore making sales more durable in an economic downturn. They find that CSR brought a significant reduction in a firm's beta. The work of Choi \& Wang (2009), that good stakeholder relations improve a company's resilience, is also likely to have relevance in adverse macro-economic circumstances. Oikonomou et al. (2012) find that corporate social responsibility is negatively but weakly related to systematic risk, but that corporate social irresponsibility is positively and strongly related to systematic risk. With growing interest in the relevance of CSR for reducing a firm's cost of capital, it becomes appropriate to consider how relevant it is to determining value. We explore this with our final hypothesis.

Hypothesis 3. Higher CSR firms will have lower systematic risk exposures.

\section{Data and Methodology}

Our measures of CSP are from the Kinder, Lydenberg, and Domini (KLD) database and covers the period 1992-2009. The KLD database provides an assessment of firms according to environmental, social and corporate governance criteria. ${ }^{4}$ The data starts from 1991 with a coverage of 650 firms, composed largely of S\&P 500 firms. By 2001, the coverage extended to 1100 firms by including firms in the Russell 1000 index. Beginning in 2003, the sample extends to 3100 firms including firms included in the Russell 3000 index. Our initial sample therefore consists of U.S. firms for which CSR data is available from the KLD database. Essentially, the KLD data takes the form of a series of zero-one variables for a number of

\footnotetext{
${ }^{3}$ Precisely, beta is the firm's standard deviation of the firm's return multiplied by the market's standard deviation of return multiplied by the correlation between the firm's and the market's return, divided by the market variance of returns (i.e. the firm's covariance of return with the market return, divided by the market variance).

${ }^{4}$ This database is well-known in the CSR literature and more detailed descriptions of KLD database can be found in Hillman and Keim (2001), Mattingly and Berman (2006), Bird et al. (2007) and Barnett and Salomon (2012).
} 
strengths and concerns across the following CSR indicators: Community; Governance; Diversity; Employees; Environment; Human Rights and Product. The number of strengths and concerns differ between indicators, are not symmetrical, and can change over time as new concerns emerge or fail to be important. For instance, in the Environment indicator, climate change first appeared as a concern in 1999. In our analysis we omit the governance and human rights indicators. The Human Rights indicator is omitted partly due to missing observations in the early years and partly due to how involvement with certain countries that would have been seen as a concern has changed over time (see Gregory and Whittaker, forthcoming). The Governance indicator is omitted partly as it differs from those usually used in the governance literature (Kempf and Osthoff, 2007) and partly due to the fact that the Governance dimension includes high levels of executive pay as a concern, and low levels as a strength, which is problematic if executive pay includes performance related elements (Gregory and Whittaker, forthcoming). Appendix A describes the strengths and concerns of each dimension that we consider. One feature of the KLD data is that the mean number of strengths and concerns is low, at less than one in all cases, suggesting that a large number of firms have neither strengths nor weaknesses. Consequently we employ an alternative classification of CSR suggested in Fernando et al. (2010). Their paper simplifies the KLD rankings on environment by categorizing firms into four groups: 'Green' firms, which have only strengths; 'Toxic' firms which have only concerns; 'Grey' firms which have some strengths and some concerns; and 'Neutral' firms which have neither strengths nor concerns. We adopt this classification for all categories of CSR, and retain the Fernando et al.(2010) labels for clarity and convenience. Our reason for doing this is as follows. Although in principle we would expect the number of strengths and concerns to contain more information than dummy variables, such as 'Green' or 'Toxic' firms, one potential disadvantage of using the number is that it assumes a linear relationship between the strength or concern count and their value. If, for example, market values are driven down by a number of socially responsible investors exiting the market for stocks with any weaknesses in a certain CSR category, then it is perfectly possible that the relationship between value and number of strengths or concerns is non-linear. Furthermore, some firms have both strengths and weaknesses for given indicators, and so one might argue that the Fernando et al. (2010) categorization is a cleaner one. However, for completeness, in addition to using 'Green' and 'Toxic' dummy variables in our tests for valuation, forecasted profitability, and the estimation of implied cost of equity capital and growth rates described below, we also show the results based on the number of strengths and weaknesses. 
Our tests for systematic risk differences, which rely on realised returns, require a portfolio formation rule. The distributional properties of individual KLD indicators are such that it is not possible to form 'clean' portfolios based upon quantiles, so the only unambiguous portfolio formation rule is either to employ the Fernando et al. (2010) definition, or to form a classification based upon whether net scores are positive, negative or zero. The former has the advantage of giving clean classifications in cases where firms have both strengths and concerns, so we prefer it here. ${ }^{5}$ Note that this categorisation gives conservative groupings for the 'overall' CSR indicator, where firms are required to have strengths in at least one dimension and weaknesses in no dimension to be classified as 'Green' (and vice-versa for 'Toxic').

To test our hypotheses, we also require data on share prices and returns, accounting data and analysts' forecast data. The source of share price and returns data is CRSP. Following Fama and French (1993), accounting data (and KLD data) as of December of year $\mathrm{t}$ are matched with share prices in June of year $t+1$. If markets are efficient, this should ensure that all financial information for the financial year ended in year $t$, and any information in KLD indicators for year $\mathrm{t}$, have been embedded in share prices. The source for all accounting data is COMPUSTAT, from which we collect the following pieces of accounting information required for our analysis. These are: Book Value per share (BVPS); Net Income per share (NIPS); Long-Term Debt and Total Assets from which we construct a measure of Leverage as the ratio of Long-Term debt to total Assets (LTDTA), Sales and; R\&D spending per share (RDPS). The source for the investment analysts' earnings forecast data is the Thomson Reuters Institutional Brokers' Estimate System (IBES), from which we obtain the consensus (mean) analysts forecasts of earnings and forecasted growth rates. To avoid problems with forecasts being possibly contaminated with interim information for firms with differing financial year ends, we eliminate from our sample all firms that do not have a December financial year end. ${ }^{6}$ For our tests that do not require analysts' forecast data, the KLD data is then cross matched with CRSP and COMPUSTAT, which results in a sample of 16,758 firmyear observations. Where we use IBES data, the sample size reduces to 13,089. Finally, where $R \& D$ expenditure is missing, we set the value to zero. ${ }^{7}$

\footnotetext{
${ }^{5}$ If a firm has both strengths and concerns, it is unambiguously 'Gray' using the Fernando et al (2010) categorisation. By contrast, the net score could be positive, negative or zero in such circumstances.

${ }^{6} \mathrm{We}$ are grateful to an anonymous reviewer for pointing out this potential difficulty.

${ }^{7}$ Note that for our sample of US firms, while the reporting of the expense is mandatory, there is always the materiality consideration. An entity may choose not to report such an amount if it is viewed as non-material.
} 


\section{Research Method}

\section{Analysis of the impact of CSR on firm value}

The valuation model we employ is based on the framework developed by Peasnell (1982) and Ohlson (1995) described in (2) above. The specification in (2) shows that the current price is the sum of a discounted abnormal earnings stream and current book value. Ohlson (1995) and Rees (1997) show that under certain assumptions about constant long run growth rates in abnormal earnings, the specification in (2) can be rewritten as a weighted sum of book values and current earnings. In addition, Ohlson (1995) introduces the notion of an "other information parameter", which reflects information that is not captured in current earnings or book values but nevertheless affects the market value. This type of approach gives the theoretical underpinning for the class of models estimated in the accounting literature to determine whether additional information influences stock prices (e.g. Barth, Beaver and Landsman, 1992). The general form of these models can be summarized (suppressing firm subscripts for clarity) as:

$$
\mathrm{P}_{\mathrm{t}}=\beta_{0}+\beta_{1} \mathrm{~b}_{\mathrm{t}}+\beta_{2} \mathrm{x}_{\mathrm{t}}+\beta_{3} \vartheta_{\mathrm{t}}+\varepsilon \mathrm{t}
$$

Where, as before $b_{t}, x_{t}$ are book value and profit and $\vartheta_{t}$ is some form of 'other information'. Here, 'other information' will include our measures of CSR. In other words, we are testing whether the $\beta_{3}$ coefficients in (4) that capture the effects of our CSR indicators are significant in explaining firm valuation.

Certainly there are other approaches to addressing the question of whether markets value CSR strategies. One approach would be using Tobin's Q (which is typically proxied by calculating the firm's market value to book asset value ratio) to compare the Q-ratios of high and low CSR firms, and this is the approach taken in Guenster et al. (2011). However, this measure has several shortcomings. First, it is relatively atheoretic (Gregory and Whittaker, forthcoming). Second, it cannot readily incorporate the effects of intangibles which appear relevant in explaining CSR effects (McWilliams and Siegel, 2000; Surroca et al., 2010). Third, any differences in Q-ratios between firms are simply assumed to be attributable to CSR, yet they could easily be a consequence of differences in business models or to firm-specific accounting choices (which would affect the book values).

So our view is that it is entirely reasonable to assume $R \& D$ expenditures are approximately zero when they are not disclosed. Unreported robustness checks on firms that only have reported values confirms that this does not seem to qualitatively affect the results, save for the sample size being considerably smaller. 
McWilliams and Siegel (2000) establish the case for the effect of intangibles by including expenditure on $R \& D$ and advertising, as control variables when estimating the financial performance of CSR. We include R\&D expenditure (see above and footnote 6), but for our sample of US firms and for the duration of study the disclosure of advertising expenditure was effectively voluntary within certain limits (Simpson, 2008) and therefore zero amounts are likely to reflect strategic reporting decisions by firms. Given the fact that advertising expenditure data are not reliably available, we do not include advertising as a control. In relation to intangibles, note however, that we are silent on the Surocca et al. (2010) hypothesis and do not attempt to model any feedback loop between CSR and intangibles. We simply attempt to investigate whether CSR adds anything to firm value once the impact of our proxy for expenditure on intangibles has been controlled for.

Our specific valuation model is based upon the Barth et al. (1992) and Barth et al. (1998) implementations of the model described in (4) above. We run a regression of share price on book value per share (BVPS), net income (or earnings) per share (NIPS), control variables for SIZE (log of total assets [LOGAss] or log of sales [LOGSal) and leverage (LTDTA - which is computed as the ratio of long term debt to total assets) plus a vector of "other information" variables. These "other information" variables are: a proxy for intangible assets, $\mathrm{RDPS}_{\mathrm{it}}$, which is the R\&D expenditure per share for firm $i$ in year $t$ and a set of CSR measures derived from KLD data. The regressions are run for each CSR indicator individually and for all CSR indicators in combination. In our valuation tests, we run two specifications of the regression model. In the first specification the $S_{t r} r_{i t}$ and Con $_{i t}$ are simply the number of strengths and concerns respectively, for each indicator. When running the regressions over all the CSR indicators together, we use an overall measure of strength (OverStr) and an overall measure of concern (OverCon). OverStr is simply the sum of the number of strengths and OverCon is the sum of the number of concerns across all the CSR indicators, respectively. Formally, our model is:

$\mathrm{P}_{\mathrm{it}}=\sum_{\mathrm{j}=1}^{\mathrm{j}=10} \beta_{0 \mathrm{j}} \mathrm{IND}_{\mathrm{jit}}+\beta_{1} \mathrm{BVPS}_{\mathrm{it}}+\beta_{2} \mathrm{NIPS}_{\mathrm{it}}+\beta_{3} \mathrm{LTDTA}_{\mathrm{it}}+\beta_{4} \mathrm{SIZE}_{\mathrm{it}}+\beta_{5} \mathrm{RDPS}_{\mathrm{it}}+\beta_{6} \mathrm{Str}_{\mathrm{it}}+\beta_{7} \mathrm{Con}_{\mathrm{it}}+\varepsilon \varepsilon_{8 \mathrm{it}}$

Where $\operatorname{Str}_{i t}$ and $\mathrm{Con}_{i t}$ are KLD strength and concern indicators respectively for firm $i$ in year $t$. 
Our alternative specification employs dummy variables for KLD strength and concern indicators defined using the Fernando et al. (2010) classification, as opposed to the numbers of strengths and concerns. For each CSR indicator firms are classified as 'Green' if they only have strengths and 'Toxic' if they only have weaknesses, so that the model becomes:

$\mathrm{P}_{\mathrm{it}}=\sum_{\mathrm{j}=1}^{\mathrm{j}=10} \beta_{0 \mathrm{j}} \mathrm{IND}_{\mathrm{jit}}+\beta_{1} \mathrm{BVPS}_{\mathrm{it}}+\beta_{2} \mathrm{NIPS}_{\mathrm{it}}+\beta_{3} \mathrm{LTDTA}_{\mathrm{it}}+\beta_{4} \mathrm{SIZE}_{\mathrm{it}}+\beta_{5} \mathrm{RDPS}_{\mathrm{it}}+\beta_{6} \mathrm{Green}_{\mathrm{it}}+\beta_{7}$ Toxic $_{\mathrm{it}}+\varepsilon$ sit (6)

To allow for industry effects, our regression model is estimated with industry dummy variables (defined using Fama-French 48 industry groups). ${ }^{8}$ All our regression tests are conducted using the two-way cluster robust standard error (or CL-2) approach of Petersen (2009), which Gow et al. (2010) show to yield well-specified standard errors in accounting panel data simulations. Using CL-2 yields well-specified standard errors when fixed effects models do not. As Petersen (2009) points out, choosing the correct approach depends upon the likely form of dependence in the data. If CSR scores are likely to be 'sticky' for a firm across time, then the research design needs to be robust to both time and firm effects, and so our standard errors are clustered on firm and year.

\section{Analysis of the impact of CSR on short term profitability, earnings growth and the cost of capital.}

Our analysis of the impact of CSR on firm value amounts to a test of whether the coefficients on Strengths and Concerns (or dummy variables for 'Green' and 'Toxic') in (5) are significant. Having investigated the valuation effects of CSR, the analysis is developed to consider where any impact of CSR on valuation comes from. Equation (2) reveals that it can come from three sources: short term earnings, longer term earnings-which depend on the growth rate, and the cost of capital.

We start with an analysis of realised returns, and we investigate the cost of capital differences between 'Green' and 'Toxic' firms by forming portfolios of these stocks and estimating the Fama-French three factor (1996) model in (7) below. The three factor model in (7) extends the CAPM in (3) and provides a richer way to model exposure to systematic risk. The model

\footnotetext{
${ }^{8}$ From Ken French's data library: http://mba.tuck.dartmouth.edu/pages/faculty/ken.french/data_library.html Results are robust to an alternative 10 -industry classification.
} 
considers two additional factors ${ }^{9}$ : a size factor (SMB) and a value factor (HML) which proxy for systematic risk factors not fully captured by the simple specification of the CAPM and the coefficients on these factors represent exposure to systematic risk factors beyond the market index beta. ${ }^{10}$

$$
\mathrm{R}_{\mathrm{pt}}-\mathrm{R}_{\mathrm{ft}}=\alpha_{\mathrm{p}}+\beta_{\mathrm{p}}\left(\mathrm{R}_{\mathrm{mt}}-\mathrm{R}_{\mathrm{ft}}\right)+\mathrm{s}_{\mathrm{p}} \mathrm{SMB}_{\mathrm{t}}+\mathrm{h}_{\mathrm{p}} \mathrm{HML}_{\mathrm{t}}+\varepsilon_{\mathrm{pt}}
$$

As in Edmans (2011), the model is also run on an industry adjusted basis, by forming an industry matched control portfolio $\left(R_{p j t}\right)$, where each firm in the CSR portfolio is matched with its Fama-French 48 industry return. ${ }^{11}$ We then run the regression:

$$
\mathrm{R}_{\mathrm{pt}}-\mathrm{R}_{\mathrm{pjt}}=\alpha_{\mathrm{p}}+\beta_{\mathrm{p}}\left(\mathrm{R}_{\mathrm{mt}}-\mathrm{R}_{\mathrm{ft}}\right)+\mathrm{s}_{\mathrm{p}} \mathrm{SMB}_{\mathrm{t}}+\mathrm{h}_{\mathrm{p}} \mathrm{HML}_{\mathrm{t}}+\varepsilon_{\mathrm{pt}}
$$

The regression in (8) should control for any industry effects not picked up by the factor loadings. Given the company level analysis in our valuation regressions, regressions (7) and (8) are estimated using equally weighted portfolios and robust standard errors. ${ }^{12}$

For our analysis of profitability and growth rates, our approach is designed to makes full use of the information available in analysts' forecasts by employing the Lee et al. (1999) version of the Ohlson/Peasnell (OP) model, ${ }^{13}$ which can be written as:

$$
\mathrm{P}_{\mathrm{t}}=\mathrm{b}_{\mathrm{t}}+\sum_{\tau=1}^{\mathrm{n}} \frac{\left(\mathrm{FROE}_{\mathrm{t}+\tau}-\mathrm{r}_{\mathrm{e}}\right)}{\left(1+\mathrm{r}_{\mathrm{e}}\right)} \mathrm{b}_{\mathrm{t}+\tau-1}+\frac{\left(\mathrm{FROE}_{\mathrm{n}}-\mathrm{r}_{\mathrm{e}}\right) \mathrm{b}_{\mathrm{n}-1}(1+\mathrm{g})}{\left(\mathrm{r}_{\mathrm{e}}-\mathrm{g}\right)\left(1+\mathrm{r}_{\mathrm{e}}\right)^{\mathrm{n}}}
$$

Where $g$ is the long run growth rate from year $n$ onwards, FROE $_{t+\tau}$ is the forecasted return on equity for period $t+\tau$, computed as forecast EPS for period $t+\tau$ / book value of equity for

\footnotetext{
${ }^{9}$ The additional factors are motivated by the observation that average returns on stocks of small stocks and on stocks with a high book to market ratio (value stocks) have been historically higher and as such may represent proxies for exposures to sources of systematic risk not captures by CAPM.

${ }^{10}$ Note that results are robust to the use of the alternative Carhart (1997) four-factor model, which uses an additional momentum factor in addition to the three systematic risk factors in the three factor model. However, as our context is corporate cost of capital, we prefer the three factor model given the ambiguity on whether momentum is a rationally priced risk factor or an anomaly.

${ }^{11}$ All industry returns are from Ken French's data library.

12 Value-weighted results are available from the authors on request.

${ }^{13}$ Strictly, although Lee et al. (1999) claim that their model is based on Ohlson (1995) it is actually a version of the Peasnell (1982) model, as there is neither an "other information" parameter, nor a "linear information dynamic" in the model estimated.
} 
period $t+\tau-1$. As in (2), the above is a valuation expression for the firm in terms of its 'residual income' or 'abnormal earnings'. The key difference between this model and the version of the model described by (2) is that in (9) a form of constant growth is assumed beyond year $\mathrm{n}$, with specific forecasts of income being allowed for years $t$ to $n$. This has the advantage of allowing us to use analysts' earnings forecasts for years $t$ to $n$, and then solve the expression for the long run growth rate, g, implied by the share price, $\mathrm{P}_{\mathrm{t}}$. Of course, we could solve (9) for the implied cost of equity capital (ICEC), $\mathrm{r}_{\mathrm{e}}$, implied by $\mathrm{P}_{\mathrm{t}}$ but to do so requires an assumption that long run growth is consistent between all firms in an industry, irrespective of their level of CSR. ${ }^{14}$

The Barth et al. (1998) approach in (5) and (6) and the Lee et al. (1999) approach in (9) are complementary for several reasons. First, from a conceptual point of view, the Lee et al. (1999) model can only be solved for either ICEC, or growth, but not both simultaneously. Given that, a priori, we might expect both a cost of capital effect and a cash flow effect from CSR, the Barth et al. (1998) model allows us to avoid ascribing valuation effects to either ICEC or growth in the first instance. Second, the growth effects in the above model are potentially complex, as short term growth in residual income can differ from long run growth. In this respect, the Lee et al. (1999) model is useful, as it allows us to embed the full information in analysts' forecasts. IBES provides a consensus analysts' forecast for 2-3 years ahead. However, we note that the coverage is more extensive when we consider the first two years of analyst's forecasts and therefore in our analysis below, we restrict the model to two periods i.e. $\mathrm{n}=2$ in (9) above. Using the model in (9), embedding the analysts' consensus forecasts enables us to provide the following analyses.

First, we analyse differences in short term profitability (based on forecast ROE) by considering the one year ahead and two year ahead forecasted ROE directly from analysts' forecasts of earnings up to two years ahead. We operationalise this by a regression of forecasted ROE on either the log of total assets (our proxy for size) or alternatively the log of sales (an alternative proxy for size), leverage, current R\&D expenditure, and a dummy variable for the Fama-French 48 industry membership. All regression tests are estimated with Petersen (2009) cluster robust standard errors, and test for differences between CSR groupings are made using an F-test. For this analysis, we consider both the Fernando et al.

\footnotetext{
14 This is one of the approaches taken in El Ghoul et al. (2011), who find that for two CSR indicators (environment and employee relations) high CSR firms have a lower implied equity cost of capital.
} 
(2010), 'Green', 'Toxic', 'Grey' and 'Neutral' classifications (with 'Neutral' being the base category) as well as based number of CSR strengths and concerns.

Second, we test for differences in long run implied growth between 'Green' and 'Toxic' firms using the model in (9) by each CSR category, holding $r_{e}$ constant on an industry-wide basis. Note that, since we restrict $n=2$, the growth rates represent the growth rate in residual earnings from the end of year 2 to infinity. As we shall show below, whilst 'Green' firms appear to have lower risk exposures than 'Toxic' firms, most of these differences appear to be attributable to industry effects. Accordingly, we estimate an industry-specific cost of capital for each of the Fama-French 48 industry groups. To do so we use the ten year Treasury Bond rate each year, and given the evidence in Claus and Thomas (2001), set the market risk premium at 3.4 percent (although we sensitise our results using alternative estimates of three percent, four percent and five percent, this broad range being consistent with Dimson et al. (2011)). We then calculate rolling industry betas each year using the previous 60 months of returns, by employing the industry portfolio and market factor returns from Ken French's website. These betas are employed in a simple CAPM framework to give time-varying industry cost of capital. The industry specific cost of capital is then calculated as the ten year US Treasury Bond rate + (industry beta $x$ the market risk premium). Note that, in these estimations, we do not employ the Fama-French (1993) or the Carhart (1997) model when estimating an industry cost of capital given the difficulty of calculating a rational expected risk premium for the SMB, HML and MOM factors. ${ }^{15} \mathrm{As}$ in the case of the analysis of short term profitability, we operationalise the analysis by a regression of the growth rates (implied by the analyst's forecasts of earnings, current prices and calculated industry cost of capital estimates) on log of total assets (our proxy for size) or log of sales (our alternative proxy for size), leverage, current R\&D expenditure, and a dummy variable for the Fama-French 48 industry membership. Again, all regression tests are estimated with Petersen (2009) cluster robust standard errors, and tests for differences between CSR groupings are made using an Ftest. For this analysis, we again consider both the Fernando et al. (2010), 'Green', 'Toxic', 'Grey' and 'Neutral' classifications (with 'Neutral' being the base category) and also employ the number of CSR strengths and concerns.

\footnotetext{
${ }^{15}$ Given this, we also re-ran our tests using an assumption that all industries have a true beta of unity, i.e. we assume that in any given year, all firms face the same cost of capital. The results were qualitatively identical.
} 
Finally, we note that one limitation is that in (9) above, we can either assume the firmspecific cost of capital is known, or that the rate of terminal growth is known. We have set out the argument for why we believe the known cost of capital assumption is more reasonable. However, there is an alternative approach that exists in the accounting literature, developed in Easton et al. (2002), that simultaneously estimates the implied cost of equity and growth rate in stock prices. Simultaneous estimation is based on the logic that assumption of any implied expected rate of return will invariably affect the estimates of the growth rate and vice-versa. However, simultaneous estimation comes at a cost, in that it is impossible to estimate these two parameters at individual stock level, and they can only be solved for at portfolio level. The model is developed in detail in Easton et al. (2002, pp 660663), but its implementation is described by the regression in expression (8) in their paper, which is:

$$
\mathrm{X}_{\mathrm{jCT}} / \mathrm{b}_{\mathrm{j} 0}=\gamma_{0}+\gamma_{1}\left[\mathrm{P}_{\mathrm{j} 0} / \mathrm{b}_{\mathrm{j} 0}\right]+\mathrm{e}_{\mathrm{j} 0}
$$

Where:

$\mathrm{X}_{\mathrm{jCT}}$ is the aggregate $\mathrm{n}$-forecast period cum-dividend earnings ${ }^{16}$

$\gamma_{0}=\mathrm{G}-1=\left(1+\mathrm{g}^{\prime}\right)^{\mathrm{n}}=1+$ the expected rate of growth in the $\mathrm{n}$-forecast period residual income

$\gamma_{1}=R-1=\left(1+r_{e}\right)^{n}=1+$ the $n$-forecast period expected return on equity.

As Easton et al. (2002) and Easton and Sommers (2007) show, we can solve for R and G by estimating the regression implied by (10). This model is generalisable to any period for which forecasts are available, but as we have full forecasts for two years ahead, with sometimes more generalised earnings growth estimates beyond year 2, in this paper we set $n=2$ to make full use of those forecasts. We note, though, that Easton and Somers use forecasts just one period ahead and we estimate the model on this basis as a robustness check. Note that in this model ' $G$ ' is defined as the expected average annual growth rate in residual income from the date at which earnings forecasts are made, which differs from the definition of ' $\mathrm{g}$ ' in equation (9), which refers to the expected growth in residual income from the final year for which the forecast is available.

\footnotetext{
16 Defined as in equation (4) from Easton et al (2002).
} 
In order to conduct this analysis, we run the regression model in (10) for portfolios sorted on year, Fama-French 10 industry group, and portfolios formed on the basis of their CSR classification. We choose a 10-industry grouping here, rather than 48-industry groupings, in order to have a reasonable number of firms in each industry-year-class group. We provide simple t-tests for differences between these growth and ICEC estimates (i.e. without any controls). We also report the results of the analysis where we control for size, R\&D and leverage effects by running regressions of the simultaneously derived implied growth rates, the implied costs of equity capital, and the implied differences between ' $R$ ' and ' $G$ ' on SIZE (either our log assets or log sales measure), leverage, current R\&D expenditure and CSR dummies based on Fernando et al. (2010) 'Green', 'Toxic', 'Grey' and 'Neutral' classifications (with 'Neutral' being the base category).

\section{Results}

A summary of the KLD indicators of CSR and the correlations between strengths and weaknesses across the various dimensions of CSR is given in Table 1.

\section{Insert Table 1 here}

The general pattern that emerges from the analysis of the correlations is that strengths are correlated across CSR categories, as are concerns. This suggests that firms adopt coherent CSR policies across different dimensions, and justifies the inclusion of a compound measure of CSR. However, whilst strengths and concerns are generally not correlated, there is a correlation of 0.35 between Environmental strengths and concerns. The Fernando et al. (2010) definition of 'Grey' firms, as opposed to 'Green' and 'Toxic' firms is useful for dealing with any issues caused by this type of correlation. Most of the relationships between $\mathrm{R} \& \mathrm{D}$ and strengths are significantly positive. Concerns show lower levels of correlation apart from Environment concerns. Taken as a whole, these relationships, most particularly with R\&D, are consistent with the Surocca et al. (2010) evidence on CSR being mediated through intangibles. However, the relatively small correlations might also imply that there are important aspects of CSR which are uncorrelated with these intangible assets.

\section{Analysis of the association between CSR and firm value}

Our first set of valuation results, reported in Table 2, show how market prices capture the individual effects of CSR strengths and concerns as specified by equations (5) and (6). We show the regression results for each dimension of CSR. For each regression we report the coefficients and t-statistics for each of Book Value (BVPS), Net Income (NIPS), Leverage 
(LTDTA), Size (LOGass), R\&D expenditure (RDPS), and the individual CSR indicator strengths and concerns. Notably, in all cases book value, net income, LOGass and R\&D expenditures always show a significant positive relationship with value. Leverage on the other hand shows a negative relationship with value. The coefficients on RDPS indicate that markets treat such expenditure as creating an asset with a life well beyond the current period. Note that the reported regressions show the result of using the log of total assets as the size control. Results using the log of sales are not reported for space reasons, but are qualitatively similar, although using the $\log$ of assets moderately improves the R-squareds of the regressions.

\section{Insert Table 2 here}

With the individual CSR strengths and concerns, a priori we might expect weaknesses to detract from value by causing either reputational damage, and/or because they indicate poor management. Conversely, positive investment in CSR activities might be expected to enhance value. However, if agency problems exist, there is a possibility that managers may over-invest in CSR, so that the costs of the CSR programme outweigh the likely benefits. If this occurs, strengths may detract from, rather than add to, firm value. The first point to note from the regressions in Table 2 is that markets appear to view strengths and weaknesses differently. For Employee, they appear to value strengths significantly positively and concerns significantly negatively. For Community, Diversity and Environment concerns are negatively valued and significantly so. Strengths on the other hand although postive are not significant. For Product however, strengths are positively valued and significant, but concerns are not significantly negative. Overall, we note that for all indicators the sign on the coefficient on strengths is positive and that on concerns is negative, even in cases where these are not significant. Finally, across all the indicators together, strengths (OverStr) are significantly positive and concerns (OverCon) are significantly negative.

The coefficients can be interpreted as the average $\$$ amount the market adds to, or deducts from, the average share price for each strength or concern indicator. In interpreting these coefficients it is important to realise that that there is considerable divergence between the number of strengths and concerns for each indicator (see Table 1). For example, Diversity has a maximum of seven strengths whilst Product has only three. Environment has the maximum number of potential concerns at six, whilst Diversity has a maximum of two. This means that we cannot simply compare coefficients across strengths and weaknesses between indicators, or even within indicators, to gain any sense of the relative importance of such indicators 
without being aware of relative scales. For example, a firm that scores the maximum of two concerns on Diversity would be expected to suffer a fall of $(2 \times \$ 1.362)$ in its share price, whereas a firm scoring the maximum of six Environment concerns would show a decrease of $(6 \times \$ 1.557)$.

In Table 3 we report the results based on the specification in (6) using the Fernando et al. (2010) classification for each CSR indicator.

\section{Insert Table 3 here}

What we see emerge clearly from these regressions is the confirmation of all the Table 2 results with respect to strengths, in that 'Green' firms (i.e. those with only strengths) are more highly valued, whilst 'Toxic' firms (those with only concerns) have lower values. 'Green' firms are valued positively and significantly so for Diversity, Employee and Product. Results with respect to concerns show that for all categories except Diversity and Product, the concerns are negative and significant, this is also consistent with the results we obtain in table 2. We also explore the effect of combined indicators, using our overall measure of 'greenness' and 'toxicity'. Recall that the way this overall variable is set up requires a firm to have at least one strength and no concerns in any dimension to be classified as 'Green', or conversely at least one concern and no strengths in any dimension to be classified as 'Toxic', so that firms classified by this overall indicator are either unambiguously 'good' or unambiguously 'bad' in CSR terms. This is different from the Overall indicator in Table 2 which uses the simple sums of strengths and weaknesses. The result from table 3 shows (and confirms the result from table 2) that the overall package of concerns has a significantly negative impact on firm value and the overall package of strengths has a significant positive impact on value.

\section{Analysis of short term profitability, earnings growth and the cost of capital.}

Having shown that markets appear to value various dimensions of CSR, we now turn to an analysis of whether those effects are driven by differences in growth and profitability prospects, or by differences in the cost of capital. As cost of capital is central to both the interpretation of profitability differences and any calculation of the implied long run growth, we start with an analysis of realised returns using the models in (7) and (8). In Table 4 Panel A we report the results of a portfolio formed on the basis of a 'Green' classification. In Panel $\mathrm{B}$, we report the results of a portfolio formed on the basis of a 'Toxic' classification. In Panel 
$\mathrm{C}$ we report the results of a portfolio that is long in green stocks and short in toxic stocks. These are formed for each dimension individually, so that for any indicator the 'Green' portfolio includes all stocks classified as 'Green', with the 'Toxic' portfolio including all stocks classified as 'Toxic' for that dimension, For the 'Overall' dimension a 'Green' ('Toxic') stock must be 'Green' ('Toxic') across every dimension to be included. Due to space constraints we simply report the differences between 'Green' and 'Toxic' stocks, when we consider the industry adjusted model (Panel D).

\section{Insert Table 4 here}

The risk exposures to the systematic risk factors are captured by the loading (the coefficients) on the market factor $(r m-r f)$, size factor $(s m b)$ and a value/growth factor $(h m l)$. Overall, we note that Panels A and B show that the Fama-French three-factor model appears to do a reasonable job of explaining the portfolio returns, that there is some evidence of size effects being important, and that all the portfolios have some exposure to the HML factor. In terms of differences in risk exposures, reported in Panel C, an F-test indicates that all regressions except for those based on Community are statistically significant, and show that 'Green' firms have lower market beta (i.e. the coefficient on $r m$-rf) compared to 'Toxic' firms across all the dimensions (except Product). This is consistent with the evidence in Sharfman and Fernando (2008), although we note that the difference on the Overall indicator is not significant. Exposure to the SMB factor is mixed, with the Overall difference being insignificant, the Diversity difference being negative and the Environment and Product differences being significantly positive. For each of Community, Employee, Environment and Product, together with the Overall indicator, 'Green' firms have a significantly lower exposure to the HML factor, although we again note the lack of significance of the Community regression. In theory, book to market ratios capture growth prospects so that this lower exposure to HML is consistent with high CSR stocks being less exposed to low growth areas of the economy. For example, technology stocks in general tend to have low HML exposures whereas heavy industry stocks tend to have high exposures.

However, many of these differences lose their significance when estimated on an industry adjusted basis, suggesting that some of these risk differences are attributable to industry effects. On an industry-adjusted basis, reported in Panel D, only Community and Environment exhibit a significantly lower market beta for 'Green' firms compared to 'Toxic' firms. Here, all of the regressions are statistically significant, and show that the SMB exposure difference is significantly negative for Community, Diversity and Employee (at 10\% significance only). 
Only product has a significantly higher exposure to SMB. All the HML risk exposures differences between 'Green' and 'Toxic' firms are insignificant except for Product where 'Toxic' firms have higher exposures.

Net of industry effects, overall the implied cost of capital differences are small. If we take the Claus and Thomas (2001) estimate of the expected market risk premium (3.4 percent p.a.) and the long run (1927-2009) historical mean annualized estimates of SMB and HML (3.6\% and $5.00 \%$ ) from Ken French's website, net of industry effects the cost of capital difference between 'Green' and 'Toxic' firms using the significant coefficients from Table 4 would be only $0.63 \%$ in the case of Diversity, and less for all other categories. For the Overall category, the implied difference in cost of equity equates to only $0.19 \%$ p.a. based upon these historical averages. However, we note that Fama and French (2011) provide evidence that the "price" of SMB risk has not been significantly different from zero in the period since 1990, implying that the cost of equity difference for the Overall category may simply be zero. So taking these figures in conjunction with the results in Tables 2 and 3, it seems likely that the cost of capital impact of CSR is likely to be dominated by the expected future profit element. ${ }^{17}$

Next we examine the expected one year ahead profitability (Table5) and two year ahead profitability (Table 6) based on the analysts' consensus forecasts of earnings, and then derive the long run growth (Table 7) implied by these forecasts. In all of this analysis, consistent with Table 2 and Table 3, we consider both the Fernando et al. (2010), 'Green', 'Toxic', 'Grey' and 'Neutral' classifications (with 'Neutral' being the base category) ${ }^{18}$ in Panel A of each Table, and the number of CSR strengths and concerns in Panel B of each Table. Within each Panel, we first report the results from a regression of the forecast profitability (or implied long run growth) on the CSR indicator, dummy variables for Fama-French 48 industry membership, size, leverage and R\&D. Our main results report the results where the $\log$ of assets is used as the size control. In addition to reporting the regression tests, we report the results from an F-test (together with the associated p-value) for the difference between the 'Green' and 'Toxic' dummies. We also report this test for difference between 'Green' and

\footnotetext{
${ }^{17} \mathrm{We}$ also note a small but marginally significant alpha for the Overall indicator for the industry-adjusted portfolio returns, suggesting that a portfolio long in 'Green' stocks and short in 'Toxic' stocks outperforms by about $0.141 \%$ per month on an industry-adjusted basis, although such an effect is statistically insignificant if the Carhart (1997) four-factor model is employed.

${ }^{18}$ In unreported robustness checks, we obtain similar results using an alternative 'positive', 'negative' and 'zero' net score classification.
} 
'Toxic' dummies using all the variables except that we use Sales as control for size (instead of total assets), which is shown in the Tables as ('Green-Toxic'(S)), and a t-test for differences between 'Green' and 'Toxic' without any controls ('Green-Toxic'(NC)). We start the examination of the expected future profitability using one year ahead forecasted profitability

\section{Insert Table 5 here}

For one year ahead ROE based on the Fernando et al. (2010) classification, with Total Assets as control for size, 'Green' firms with respect to the Diversity and Employee categories are significantly more profitable than 'Toxic' firms, whilst high CSR firms with respect to Environment and Product categories are less profitable, with environment being significantly so. For the Overall indicator, profitability is lower for green firms but significant only at $10 \%$ level. However, the results are not robust to use of alternative control for size. When we use sales as a size control these differences disappear. When we consider the number of CSR strengths and concerns (Panel B), the results suggest that for all categories (including Overall) except Environment, strengths have a positive impact on forecasted profitability. For Community, Product and Overall concerns a positive impact on profitability is also found. The overall conclusion that one can draw from Table 5 is that there does not appear to be any consistent and robust evidence for any superior positive impact of high CSR (measured using dummies or numbers) on one year ahead profitability.

Broadly, these effects carry through to the forecasted two year ROE. With total assets as control for size, it appears that the high-scoring firms on Diversity are significantly more profitable, whilst high-scoring firms on Environment are significantly less profitable. The Overall indicator reveals no difference in profitability between 'Green' and 'Toxic' firms.

\section{Insert Table 6 here}

As in Table 5, these effects are not robust to alternative definitions of firm size. Using sales as a control for size all of the differences except for Environment disappears. When we consider the number of strengths and concerns, both strengths and concerns have a positive impact on two year ahead forecasted profitability, with concerns showing significant positive impact in all categories but Diversity, although the coefficients are smaller compared to strengths except for Community, Environment and Product. Overall the results suggest that there is no consistent and robust difference between high and low CSR firms in terms of their two year ahead forecasted profitability. 
However, the results in Table 5 and Table 6 are based on short term forecasts, and investment in CSR may be expected to pay off only in the long run (Barnett and Salomon, 2012). Table 7 reports the results of the analysis of long term growth rates implied by analysts' forecasts of earnings and current stock prices. Note that in some cases we cannot solve for an implied growth rate, typically because the forecasted year 2 abnormal earnings is negative, but in some cases because the present value of the residual income (for one and two years ahead) plus book value already exceeds the current share price. Consequently, we eliminate such firms from our sample, leaving a sample of 10,437 firm-years for which we can feasibly compute an implied long run growth rate. Given that such estimates are inherently noisy, we Winsorise our implied growth rates at the 2.5 percent level. ${ }^{19}$ In interpreting these implied long run growth estimates, it is important to bear in mind that any short term growth in earnings (and hence abnormal earnings or residual income) have already been embedded in the valuation expression, as the $g$ we are now solving for is the growth rate to infinity in abnormal earnings (i.e. earnings in excess of that expected given the cost of capital) beyond year 2.

\section{Insert Table 7 here}

Using log assets as control for firm size, accounting for intangibles, leverage and industry effects, the long run growth rates implied by analysts' consensus forecasts are significantly higher for 'Green' firms for all CSR dimensions except for Diversity and Employee. Whilst 'Toxic' firms have lower implied growth for every dimension, the difference is insignificant except in the case of Community. However, the F-test for differences between Green and Toxic implied growth is significant for all dimensions except Employee. The results are robust to alternative definition of firm size as the differences seen with total assets as size control still retain their significance, as they do when no controls are employed. Considering the number of strengths and concerns, we note that concerns are negatively related to long term growth and in all cases except Employee and Product are significantly so. For Product and Overall the strengths are significantly positively related to long term forecasted growth and concerns are significantly negatively related to the long term forecasted growth. The evidence from Table 7 is that in the long run, abnormal earnings are more persistent in high CSR firms, suggesting that they are expected to enjoy a long run competitive advantage compared to low CSR firms. ${ }^{20}$

\footnotetext{
${ }^{19}$ Although our results are robust to Winsorising at the 1 percent and 5 percent levels.

${ }^{20}$ Other studies (in particular, El Ghoul et al. 2011) implement (6) by solving for $r_{e}$ rather than $g$. This requires $\mathrm{g}$ to be held constant across all firms. If we do so, the results are striking, with 'Green' firms having the lowest
} 
Finally, in Table 8 we show the result of solving the Easton et al. (2002) regression described in (9). Recall that we estimate this model by forming portfolios each year on the basis of CSR category and Fama-French 10 industry membership, and derive simultaneous estimates of the long run annualised growth in the base period (first two year) residual income and the cost of equity. The main estimates in the Table show the effect of regressing these growth and cost of equity estimates on controls for size (log of assets and, alternatively, log of sales), leverage and R\&D. The 'Neutral' category is the base estimate, with 'Green', 'Grey' and 'Toxic' dummy variables capturing the differences between the estimates for these categories and the 'Neutral' category. We then report the results of an F-test on whether the difference between 'Green' and 'Toxic' coefficients are significant, together with a second F-test on whether the difference is significant when log of sales is used as the size control (reported as 'GreenToxic'[S]). Finally, we show the result of a simple test on whether the "raw" estimates of growth and ICEC differ between 'Green' and 'Toxic' firms (reported in the Table as 'GreenToxic'[NC]). Panel A shows the regressions for implied growth, and Panel B shows the regressions for the implied equity cost of capital. Finally, recognising that ultimately it is the combined effect of cost of equity and growth that drive any valuation, Panel $\mathrm{C}$ shows the results of performing the same tests on ICEC minus implied growth. In each panel, figures in parentheses under row differences are p-values, calculated using simple t-tests for differences in the raw estimates and cluster robust estimates for the regression tests.

\section{Insert Table 8 here}

The results broadly support the conclusions from the earlier analysis. When we turn to implied growth, in Panel A, we find far stronger effects for growth than for the cost of equity, reported in Panel B. For the raw results, apart from Diversity, where growth is lower for 'Green' firms, growth is higher for 'Green' firms compared to 'Toxic' firms all categories of CSR by between $0.5 \%$ (Employee) and 3.8\% (Environment). Overall, growth is higher by $0.8 \%$ in 'Green' firms compared to 'Toxic' firms. Once size, R\&D expenditure, and leverage is controlled for, growth is significantly higher for Employee, Environment, Product, and Overall, but lower for Diversity and with no significant difference for Community. This result, where log assets are the control for size, is robust when we use log sales as control for size. Last, the dummy variables in the regression suggest that the growth differences

ICC for all categories of CSR except Diversity (where 'Neutral' firms have the lowest, and 'Toxic' firms have the highest, except in the case of Community where 'Grey' firms have a marginally higher ICC. Full results are available from the authors on request. 
compared with 'Neutral' firms are generally driven by the poor growth prospects of 'Toxic' firms, which are significantly negative in every case except Diversity. 'Grey' firms have lower growth prospects than 'Neutral' firms for Employee, Environment and Overall dimensions. Compared to 'Neutral' firms, 'Green' firms have better growth prospects for Diversity and Overall dimensions, but worse prospects for Community and Product dimensions.

We note that from Panel B, whilst there are significant differences in cost of equity, even net of controls, they are in differing directions. 'Green' firms on the Diversity dimension have a lower cost of equity than 'Toxic' firms, but 'Green' firms on an Environmental dimension have a higher cost of capital than 'Toxic' firms. For the Overall dimension, the cost of equity is approximately $0.2 \%$ on a raw (no controls) basis, but there are no significant differences between 'Green' and 'Toxic' firms when size, leverage and R\&D are controlled for. Finally, looking at the differences between categories compared to 'Neutral' firms, we again observe no clear patterns across differing dimension of CSR. For Overall, the implied cost of equity for 'Toxic' firms is about $0.3 \%$ higher than for 'Neutral' firms, but 'Green' firms do not have a cost of equity significantly different from 'Neutral' firms. Taken as a whole, then, the results from Panel A and Panel B confirm our earlier findings that growth differences seem more important than cost of capital differences in explaining valuations.

Of course, given these are expected returns and growth rates in the residual income expected at the time when the forecasts are made, ultimately what matters for the valuation is the difference between the cost of equity and growth, i.e. the combined effect of $r_{e^{-}} g$ in the terminal value expression which appears as the final term on the RHS of (9). Ceteris paribus, a smaller difference between the cost of equity and growth implies a higher valuation. Panel $\mathrm{C}$ shows that these differences are consistent with the valuation results from Tables 2 and 3. Results using no controls and using control (with alternative definitions for size) all show that the difference between cost of equity and growth is smaller for 'Green' firms than 'Toxic' firms. As in the case of growth, primarily the effect seems to come about because of the adverse valuation of 'Toxic' firms (compared to 'Neutral' firms), although for Diversity, Environment and Overall there is a positive valuation effect for 'Green' firms compared to 'Neutral' firms. 


\section{Discussion and conclusion}

This paper has argued that analysing valuation provides the single important indicator of how markets view CSR activity, as it captures both expected future cash flow effects and expected cost of capital effects.

Our first contribution has been to extend the analysis in Gregory and Whittaker (forthcoming) by presenting a model that separately estimates the stock market's valuation of CSR strengths and concerns across multiple dimensions. We further extend the analysis by employing the Fernando et al. (2010) classification of firms in each dimension into 'Green', 'Grey', 'Neutral' and 'Toxic' categories. Separating out strengths and concerns reveals that strengths (or 'Greenness') are significantly positively valued across Employee, and Product dimensions, with the result for Diversity only being significant when 'Greenness' is used to define the dimension. By contrast, concerns (or 'Toxicity') reduce value in all dimensions, except Product dimensions although the Diversity effect differs according to how the dimension is defined, with concerns being negatively valued but the effect being insignificant when the 'Toxicity' categorisation is used to define the dimension. For our combined Overall dimension, strengths are positively valued, weaknesses are negatively valued, being 'Green' adds value, whilst being 'Toxic' detracts from value.

So far, this is a simple extension of Gregory and Whittaker (forthcoming), but our second and main contribution is to analyse the source of these valuation differences. As we have argued, a higher valuation of CSR can arise either because such firms are expected to be more profitable in the short run, or they are expected to be more profitable in the long run, or they have a lower cost of capital. We attempt to disaggregate these effects in a number of ways. First, we employed an asset pricing model framework to investigate whether high CSR firms had lower factor exposures than low CSR firms. Consistent with Sharfman and Fernando (2008) we find that in general high performance in CSR terms is associated with lower risk factor loadings. However, with the exception of the Environment dimension, these lower factor loadings seem to be principally attributable to industry effects. Furthermore, whilst significant, such factor loading differences lead to a smaller economic impact on the implied cost of equity capital. This led us to explore the impact that CSR might have on future expected cash flows and profits. 
To investigate this, we analysed IBES forecasts of future profitability and found little robust evidence that one and two year ahead forecasted ROE differences depend on CSR, once industry membership, size, leverage and R\&D are controlled for. Next, we solved the long run residual income (or abnormal earnings) model of Lee et al. (1999) for implied long run growth whilst holding industry cost of capital constant across different CSR portfolios within each year. We find that on a control-adjusted basis there is evidence that the implied long run growth is greater for 'Green' firms than 'Toxic' firms across all the dimensions of CSR except the Employee dimension, as well as for our overall CSR indicators. For this Overall dimension, strengths are associated with better implied growth prospects and concerns are associated with lower implied growth estimates. These results are consistent with 'Green' firms being expected to enjoy a sustained competitive advantage with a longer run of abnormal earnings than low CSR firms. Finally, we estimated the Easton et al. (2002) model, which simultaneously solves for implied growth and implied cost of equity, and confirmed that, in general, growth effects seem more important than cost of equity effects.

Taken as a whole, our results show that markets positively value most aspects of CSR, and do so because in the long run, measured across most dimensions, high CSR firms have a higher expected growth rate in their abnormal earnings. In addition, although such firms might appear to have a lower cost of equity, this seems to be primarily due to industry effects rather than CSR strategy. These significant valuation effects have important implications for corporate managers, fund managers and other investors. As noted by Barber (2007, p.78) 'institutional shareholder activism designed to improve shareholder value should be well grounded in scientific evidence'. In providing evidence, derived from a robust model, that positive CSR is rewarded with increased valuations, and that the avoidance of exposures to some concerns is also rewarded, we provide justification for both managers and investors to engage in such strategies. 


\section{References}

Albuquerque, R, Durnev, A., \& Koskinen Y. (2012). Corporate Social Responsibility and Asset Pricing in Industry Equilibrium. Available at SSRN: http://ssrn.com/abstract=1961971

Aragón-Correa J.A., \& Sharma S. (2003). A contingent resource-based view of proactive corporate environmental strategy. Academy of Management Review 28(1):71-88.

Barber, B.M., (2007). Monitoring the Monitor: Evaluating CalPERS' Activism. The Journal of Investing Winter 16 (4): 66-80.

Barnett, M.L., (2007). Stakeholder influence capacity and the variability of financial returns to corporate social responsibility. Academy of Management Review 32(3):794-816.

Barnett, M.L., \& Salomon, R.M. (2012). Does it pay to be really good? Addressing the shape of the relationship between social and financial performance. Strategic Management Journal 33(11): 1304-1320

Barney, J. (1991). Firm resources and sustained competitive advantage. Journal of Management 17(1):771-792.

Barth, M.E., Beaver, W.H., \& Landsman, W.R.(1992). The market valuation implications of net periodic pension cost components. Journal of Accounting and Economics 15(Spring): 2762.

Barth, M.E., Clement, M.B., Foster, G., \& Kasznik R. (1998). Brand Values and Capital Market Valuation. Review of Accounting Studies 3(1-2): 41-68.

Benston, G.J. (1982). Accounting and Corporate Accountability. Accounting, Organizations and Society 7(2): 87-105.

Bird, R.A., Hall, A., Momente, F., \& Reggiani, F. (2007). What Corporate Social Responsibility Activities are Valued by the Market? Journal of Business Ethics 76(2): 189206.

Branco, M.C., \& Rodrigues, L.L. (2006). Corporate Social Responsibility and ResourceBased Perspectives. Journal of Business Ethics 69:111-132.

Carhart, M. (1997). On Persistence in Mutual Fund Performance. Journal of Finance 52(1): 57-82.

Choi, J., \& Wang, H. (2009) Stakeholder relations and the persistence of corporate social performance. Strategic Management Journal 30: 895-907.

Claus, J., \& Thomas, J. (2001). Equity Premia as Low as Three Percent? Evidence from Analysts' Forecasts for Domestic and International Stock Markets. Journal of Finance 56(5): $1629-1666$.

Dimson, E., Marsh, P., \& Staunton, M. (2011). Equity premia around the world. Available at SSRN: http://papers.ssrn.com/sol3/papers.cfm?abstract_id=1940165. 
Easton, P.; G. Taylor; P. Shroff; and T. Sougiannis (2002), 'Using Forecasts of Earnings to Simultaneously Estimate Growth and the Rate of Return on Equity Investment,' Journal of Accounting Research, Vol. 40, pp. 657-76.

Easton, P. and Sommers, G. (2007), 'Effects of analysts' optimism in estimates of expected rate of return implied by earnings forecasts', Journal of Accounting Research 45, 983-1015

Edmans, A. (2011). Does the stock market fully value intangibles? Employee satisfaction and equity prices. Journal of Financial Economics.101(3): 621-640.

El Ghoul, S., Guedhami., O, Kwok, C.C.Y., \& Mishra D. (2011). Does Corporate Social Responsibility Affect the Cost of Capital? Journal of Banking and Finance 35(9): 2388-2408.

Fama, E.F., \& French, K.R. (1993). Common Risk Factors in the Returns on Stocks and Bonds. Journal of Financial Economics 33(1): 3-56.

Fama, E.F. and K.R. French (2011), 'Size, Value, and Momentum in International Stock Returns', Fama-Miller Working Paper; Tuck School of Business Working Paper No. 201185; Chicago Booth Research Paper No. 11-10. Available at SSRN: http://ssrn.com/abstract=1720139

Fernando, C.S., Sharfman, M.P., \& Uysal, V.P. (2010). Does Greenness Matter? The Effect of Corporate Environmental Performance on Ownership Structure, Analyst Coverage and Firm Value. Paper presented at the 2010 FMA European Conference, Hamburg, Germany.

Flammer, C. (2013) Does Corporate Social Responsibility Lead to Superior Financial Performance? A Regression Discontinuity Approach. MIT Working paper.

Garcia-Castro, R., Ariño, M.A. and Canela, M.A. (2010). Does Social Performance Really Lead to Financial Performance? Accounting for Endogeneity. Journal of Business Ethics 92:107-126

Godfrey, P., Merrill, C., \& Hansen J. (2009). The Relationship between CSR and Shareholder Value: An empirical test of the risk management hypothesis. Strategic Management Journal 30: $425-455$.

Gow, I.D., Ormazabal, G., \& Taylor, D.J. (2010). Correcting for Cross-Sectional and TimeSeries Dependence in Accounting Research. The Accounting Review 85 (2): 483-512.

Gregory, A, Whittaker, J. (Forthcoming). Exploring the Valuation of Corporate Social Performance - A Comparison of Research Methods. Journal of Business Ethics. DOI $10.1007 / \mathrm{s} 10551-012-1465-5$

Guenster, N., Bauer, R., Derwall, J., \& Koedijk, K. (2011). The Economic Value of Corporate Eco-Efficiency. European Financial Management 17 (4):679-704.

Hart, S.L. (1995). A Natural Resource-Based View of the Firm. Academy of Management Review. 20(4): 986-1014. 
Heinkel, R., Kraus, A., \& Zechner, J. (2001). The Effect of Green Investment on Corporate Behavior. Journal of Financial and Quantitative Analysis 35 (4): 431-449.

Hillman, A.J., \& Keim, G.D. (2001). Shareholder Value, Stakeholder Management, and Social Issues: What's the Bottom Line? Strategic Management Journal 22 (2):125-139.

Hong, H., \& Kacperczyk, M. (2009). The Price of Sin: The Effects of Social Norms on Markets. Journal of Financial Economics 93: 15-36.

Jo, H., \& Harjoto, M. (2011). Corporate governance and firm value: The impact of corporate social responsibility. Journal of Business Ethics 103(3): 351-383.

Jones, T. (1995). Instrumental stakeholder theory: A synthesis of ethics and economics. Academy of Management Review 20(2): 404-437.

Kempf, A. , \& Osthoff , P. (2007). The Effect of Socially Responsible Investing on Portfolio Performance. European Financial Management 13( 5): 908-922.

Kim, Y., \& Statman, M. (2012). Do companies invest enough in environmental responsibility? Journal of Business Ethics 105: 115-129.

Lee, C.M.C., Myers, J., \& Swaminathan, B. (1999). What Is The Intrinsic Value Of The Dow? Journal Of Finance 54(5): 1693-1741.

Lubatkin, M., \& Chatterjee, S. (1994). Extending Modern Portfolio Theory into the Domain of Corporate Diversification: Does It Apply? The Academy of Management Journal 37(1):109-136.

Luo, X., \& Battacharya, C.B. (2009). The debate over doing good: Corporate social performance, strategic marketing levers, and firm-idiosyncratic risk. Journal of Marketing $\mathbf{7 3}$ (November): 198-213.

Lundholm R, O'Keefe T. 2001. Reconciling value estimates from the discounted cash flow model and the residual income model. Contemporary Accounting Research $\mathbf{1 8}$

(Summer): 311-35.

Margolis, J.D., \& Walsh, J.P. (2003). Misery Loves Companies: Rethinking Social Initiatives by Business. Administrative Science Quarterly 48 (2):268-305.

Margolis, J.D., Elfenbein, H.A., \& Walsh, J.P. (2009). Does it Pay to Be Good...And Does it Matter? A Meta-Analysis of the Relationship between Corporate Social and Financial Performance Available at SSRN: http://ssrn.com/abstract=1866371

Mattingly, J.E., \& Berman, S.L.(2006). Measurement of Corporate Social Action: Discovering Taxonomy in the Kinder Lydenburg Domini Ratings Data. Business and Society 45: $20-46$.

McGuire, J.B., Sundgren, A., \& Schneeweis, T. (1988). Corporate Social Responsibility and Firm Financial Performance. The Academy of Management Journal 31(4): 854-872. 
McWilliams, A., \& Siegel, D. (2000). Corporate Social Responsibility and Financial Performance: Correlation or Misspecification. Strategic Management Journal 21(5): 603609.

Ohlson, J.A.(1995). Earnings, Book Values, and Dividends in Equity Valuation. Contemporary Accounting Research 11(2): 661-678.

Oikonomou, I., Brooks, C., \& Pavelin.S. (2012) The impact of corporate social performance on financial risk and utility: A longitudinal analysis. Financial Management 41 (2): 483-515.

Orlitzky, M., Schmidt, F.L., Rynes, S.L. (2003). Corporate Social and Financial Performance: A Meta-analysis. Organization Studies 24(3): 403-441.

Peasnell, K.V. (1982). Some Formal Connections Between Economic Values and Yields and Accounting Numbers. Journal of Business Finance and Accounting 9(3):361-381.

Peavy, J.W. (1984). Modern Financial Theory, Corporate Strategy, and Public Policy: Another Perspective. The Academy of Management Review 9(1):152-157.

Perrini, F., Russo, A., Tencati, A., \& Vurro,C. (2011). Deconstructing the relationship between corporate social and financial performance. Journal of Business Ethics 102:50-76.

Petersen, M.A. (2009). Estimating standard errors in finance panel data sets: Comparing approaches. Review of Financial Studies 22(1): 435-480.

Preston, L. E., D. P. O'Bannon. (1997). The corporate social-financial performance relationship. Business and Society 36(4): 419-429.

Rees, W. P. (1997). The Impact of Dividends, Debt and Investment On Valuation Models. Journal of Business Finance and Accounting 24(7): 1111-1140.

Renneboog, L., Ter Horst, J. \& Zhang, C. (2008), 'Socially responsible investments: Institutional aspects, performance, and investor behaviour,' Journal of Banking \& Finance, Vol.32, pp.1723-1742.

Ruefli, T.W., Collins, J.M., \& Lacugna, J.R. (1999). Risk Measures in Strategic Management Research: Auld Lang Syne? Strategic Management Journal 20(2): 167-194.

Russo, M.V., \& Fouts, P.A. (1997) A resource-based perspective on corporate environmental risk management and profitability. Academy of Management Journal 40(3):534-559.

Sharfman, M.P., \& Fernando, C.S. (2008). Environmental Risk Management and the Cost of Capital. Strategic Management Journal 29: 569-592.

Simpson, A., (2008), Voluntary Disclosure of Advertising Expenditures. Journal of Accounting, Auditing and Finance 23(3): 404-436.

Surroca, J., Tribó, J.A., \& Waddock, S. (2010). Corporate Responsibility and Financial Performance: The Role of Intangible Resources. Strategic Management Journal 31: 463490. 
Van Beurden, P., \& Gossling, T. (2008). The worth of values - a literature review on the relation between social and financial performance. Journal of Business Ethics 82: 407-424.

Waddock, S. A., S. B. Graves. (1997). The corporate social performance-financial performance link. Strategic Management Journal 28(4) 303-319.

Wang, H., \& Choi, J. (2013). A New Look at the Corporate Social-Financial Performance Relationship: The Moderating Roles of Temporal and Interdomain Consistency in Corporate Social Performance. Journal of Management 39(2): 416-441 
Table 1. Pearson Correlation Coefficients and Summary Statistics

\begin{tabular}{|c|c|c|c|c|c|c|c|c|c|c|c|c|c|c|c|c|c|c|c|}
\hline $\begin{array}{l}\text { Variables } \\
\text { comstr }\end{array}$ & $\begin{array}{l}\text { comstr } \\
1.00\end{array}$ & comcon & divstr & divcon & empstr & empcon & envstr & envcon & prostr & procon & overstr & overcon & PPS & BVPS & NIPS & RDPS & LOGsal & LOGAss & LTDTA \\
\hline comcon & 0.14 & 1.00 & & & & & & & & & & & & & & & & & \\
\hline divstr & 0.44 & 0.17 & 1.00 & & & & & & & & & & & & & & & & \\
\hline divcon & -0.09 & -0.01 & -0.17 & 1.00 & & & & & & & & & & & & & & & \\
\hline empstr & 0.26 & 0.19 & 0.30 & -0.06 & 1.00 & & & & & & & & & & & & & & \\
\hline empcon & 0.02 & 0.12 & 0.12 & 0.08 & 0.07 & 1.00 & & & & & & & & & & & & & \\
\hline envstr & 0.20 & 0.16 & 0.24 & -0.08 & 0.30 & 0.11 & 1.00 & & & & & & & & & & & & \\
\hline envcon & 0.15 & 0.33 & 0.14 & -0.05 & 0.29 & 0.21 & 0.35 & 1.00 & & & & & & & & & & & \\
\hline prostr & 0.14 & 0.01 & 0.19 & -0.05 & 0.25 & 0.04 & 0.19 & 0.05 & 1.00 & & & & & & & & & & \\
\hline procon & 0.26 & 0.22 & 0.34 & -0.03 & 0.18 & 0.15 & 0.18 & 0.29 & 0.09 & 1.00 & & & & & & & & & \\
\hline overstr & 0.66 & 0.23 & 0.82 & -0.16 & 0.64 & 0.12 & 0.53 & 0.30 & 0.41 & 0.36 & 1.00 & & & & & & & & \\
\hline overcon & 0.18 & 0.49 & 0.22 & 0.29 & 0.26 & 0.59 & 0.29 & 0.73 & 0.06 & 0.61 & 0.33 & 1.00 & & & & & & & \\
\hline PPS & 0.09 & 0.07 & 0.08 & -0.05 & 0.06 & 0.00 & 0.04 & 0.09 & 0.10 & 0.08 & 0.11 & 0.07 & 1.00 & & & & & & \\
\hline BVPS & 0.07 & 0.08 & 0.02 & -0.03 & 0.01 & 0.02 & 0.02 & 0.09 & 0.02 & 0.06 & 0.04 & 0.08 & 0.78 & 1.00 & & & & & \\
\hline NIPS & 0.10 & 0.11 & 0.06 & -0.02 & 0.06 & 0.01 & 0.04 & 0.10 & 0.05 & 0.08 & 0.10 & 0.10 & 0.77 & 0.72 & 1.00 & & & & \\
\hline RDPS & 0.11 & -0.04 & 0.10 & -0.05 & 0.15 & 0.04 & 0.16 & 0.15 & 0.18 & 0.13 & 0.20 & 0.12 & 0.08 & 0.01 & 0.02 & 1.00 & & & \\
\hline LOGsal & 0.36 & 0.24 & 0.38 & -0.15 & 0.33 & 0.16 & 0.28 & 0.41 & 0.18 & 0.43 & 0.50 & 0.43 & 0.24 & 0.19 & 0.24 & 0.11 & 1.00 & & \\
\hline LOGAss & 0.42 & 0.30 & 0.40 & -0.16 & 0.29 & 0.08 & 0.21 & 0.34 & 0.13 & 0.41 & 0.49 & 0.36 & 0.22 & 0.23 & 0.21 & 0.01 & 0.80 & 1.00 & \\
\hline LTDTA & -0.05 & 0.05 & -0.03 & 0.00 & -0.01 & 0.04 & 0.06 & 0.11 & -0.03 & 0.03 & -0.02 & 0.09 & -0.04 & -0.05 & -0.06 & -0.07 & 0.14 & 0.19 & 1.00 \\
\hline Mean & 0.21 & 0.10 & 0.58 & 0.32 & 0.30 & 0.39 & 0.15 & 0.31 & 0.08 & 0.26 & 1.32 & 1.38 & 34.42 & 15.43 & 1.75 & 0.41 & 20.80 & 7.73 & 0.19 \\
\hline Median & 0.00 & 0.00 & 0.00 & 0.00 & 0.00 & 0.00 & 0.00 & 0.00 & 0.00 & 0.00 & 1.00 & 1.00 & 27.75 & 11.84 & 1.44 & 0.00 & 20.82 & 7.65 & 0.15 \\
\hline $\operatorname{Max}$ & 5.00 & 3.00 & 7.00 & 2.00 & 5.00 & 4.00 & 4.00 & 6.00 & 3.00 & 4.00 & 21.00 & 13.00 & 2345.00 & 1176.90 & 202.94 & 13.00 & 26.78 & 14.60 & 0.97 \\
\hline Min & 0.00 & 0.00 & 0.00 & 0.00 & 0.00 & 0.00 & 0.00 & 0.00 & 0.00 & 0.00 & 0.00 & 0.00 & 0.20 & 0.04 & -55.05 & 0.00 & 9.21 & 1.68 & 0.00 \\
\hline$S d$ & 0.56 & 0.32 & 1.02 & 0.48 & 0.61 & 0.61 & 0.45 & 0.78 & 0.29 & 0.60 & 1.96 & 1.60 & 46.03 & 24.50 & 4.23 & 0.95 & 1.84 & 1.81 & 0.18 \\
\hline
\end{tabular}

The Table shows Pearson correlations and summary statistics for the following variables: Comstr, Comcon the KLD CSR measures for community relations strengths and concerns, respectively; Divstr, Divcon, the KLD CSR measures for diversity indicator strengths and concerns, respectively; Empstr, Empcon, the net KLD CSR measure for employee relations indicator strengths and concerns, respectively; Envstr, Envcon the net KLD CSR measure for environmental indicator strengths and concerns, respectively; Prodstr, Procon, the net KLD CSR measure for product indicator strengths and concerns; Overstr - overall strength measured as the sum of strengths across all CSR indicators, Overcon-Overall concern measured as the sum of concerns across all CSR indicators respectively; PPS, the end June market price per share; BVPS, the book value per share; NIPS, the net income per share; RDPS, the Research and Development Expenditure per share ; LOGass, the natural log of Total Assets; LOGsal, the natural log of Sales and LTDTA, leverage-measured as the ratio of long term debt to total assets; Where the RDPS figures are not available in COMPUSTAT, they are assumed to be zero. 
Table 2: Regressions of price on KLD strengths and concerns

\begin{tabular}{|c|c|c|c|c|c|c|}
\hline Variable & Community & Diversity & Employee & Environment & Product & Overall \\
\hline BVPS & $\begin{array}{l}0.892 * * * \\
(9.93)\end{array}$ & $\begin{array}{l}0.895^{* * *} \\
(9.83)\end{array}$ & $\begin{array}{l}0.895^{* * *} \\
(9.92)\end{array}$ & $\begin{array}{l}0.892^{* * *} \\
(9.91)\end{array}$ & $\begin{array}{l}0.896 * * * \\
(9.92)\end{array}$ & $\begin{array}{l}0.896^{* * *} \\
(9.86)\end{array}$ \\
\hline NIPS & $\begin{array}{l}4.505^{* * *} \\
(6.29)\end{array}$ & $\begin{array}{l}4.496^{* * *} \\
(6.28)\end{array}$ & $\begin{array}{l}4.490 * * * \\
(6.28)\end{array}$ & $\begin{array}{l}4.502 * * * \\
(6.31)\end{array}$ & $\begin{array}{l}4.482 * * * \\
(6.26)\end{array}$ & $\begin{array}{l}4.493^{* * *} \\
(6.27)\end{array}$ \\
\hline LTDTA & $\begin{array}{l}-4.059 \\
(-1.45)\end{array}$ & $\begin{array}{l}-3.621 \\
(-1.27)\end{array}$ & $\begin{array}{l}-3.746 \\
(-1.30)\end{array}$ & $\begin{array}{l}-4.356 \\
(-1.51)\end{array}$ & $\begin{array}{l}-3.500 \\
(-1.24)\end{array}$ & $\begin{array}{l}-3.612 \\
(-1.24)\end{array}$ \\
\hline LOGass & $\begin{array}{l}1.630^{* * *} \\
(4.56)\end{array}$ & $\begin{array}{l}1.351 * * * \\
(3.82)\end{array}$ & $\begin{array}{l}1.541 * * * \\
(4.08)\end{array}$ & $\begin{array}{l}1.770 * * * \\
(4.57)\end{array}$ & $\begin{array}{l}1.375^{* * *} \\
(3.22)\end{array}$ & $\begin{array}{l}1.529 * * * \\
(3.64)\end{array}$ \\
\hline RDPS & $\begin{array}{l}2.521^{* *} \\
(2.19)\end{array}$ & $\begin{array}{l}2.497^{* *} \\
(2.20)\end{array}$ & $\begin{array}{l}2.503 * * \\
(2.20)\end{array}$ & $\begin{array}{l}2.653^{* *} \\
(2.29)\end{array}$ & $\begin{array}{l}2.279 * * \\
(2.01)\end{array}$ & $\begin{array}{l}2.443^{* *} \\
(2.15)\end{array}$ \\
\hline comstr & $\begin{array}{l}0.210 \\
(0.31)\end{array}$ & & & & & \\
\hline comcon & $\begin{array}{l}-1.677^{*} \\
(-1.90)\end{array}$ & & & & & \\
\hline divstr & & $\begin{array}{l}0.524 \\
(1.25)\end{array}$ & & & & \\
\hline divcon & & $\begin{array}{l}-1.362^{* *} \\
(-2.11)\end{array}$ & & & & \\
\hline empstr & & & $\begin{array}{l}0.934 * \\
(1.74)\end{array}$ & & & \\
\hline empcon & & & $\begin{array}{l}-1.887^{* * *} \\
(-2.86)\end{array}$ & & & \\
\hline envstr & & & & $\begin{array}{l}0.440 \\
(0.73)\end{array}$ & & \\
\hline envcon & & & & $\begin{array}{l}-1.557^{* * *} \\
(-3.63)\end{array}$ & & \\
\hline prostr & & & & & $\begin{array}{l}7.561 * * * \\
(3.30)\end{array}$ & \\
\hline procon & & & & & $\begin{array}{l}-0.341 \\
(-0.60)\end{array}$ & \\
\hline overstr & & & & & & $\begin{array}{l}0.670 * * * \\
(3.39)\end{array}$ \\
\hline overcon & & & & & & $\begin{array}{l}-1.095^{* * *} \\
(-3.80)\end{array}$ \\
\hline Intercept & $\begin{array}{l}9.978 \\
(1.20)\end{array}$ & $\begin{array}{l}11.896 \\
(1.48)\end{array}$ & $\begin{array}{l}11.054 \\
(1.38)\end{array}$ & $\begin{array}{l}10.310 \\
(1.24)\end{array}$ & $\begin{array}{l}11.657 \\
(1.52)\end{array}$ & $\begin{array}{l}12.424 \\
(1.58)\end{array}$ \\
\hline Industry controls & yes & yes & yes & yes & yes & yes \\
\hline $\mathbf{N}$ & 16758 & 16758 & 16758 & 16758 & 16758 & 16758 \\
\hline $\mathrm{Fp}$ & 0.000 & 0.000 & 0.000 & 0.000 & 0.000 & 0.000 \\
\hline R2 & 0.710 & 0.710 & 0.711 & 0.710 & 0.712 & 0.711 \\
\hline
\end{tabular}

The Table shows the result of regressing June price of year $t$ on net book value (BVPS) and net income (NIPS) for financial year ended t-1, together with Research and Development Expenditures (RDPS), Leverage - ratio of long-term debt to total assets (LTDTA), log Total Assets (LOGass) and the KLD strength and concern indicators. t-statistics computed using cluster robust standard errors from the two-way cluster approach of Petersen (2009) are shown in parentheses. All regressions include dummy variables reflecting membership of the Fama-French 48 industry groups. . ${ }^{*} * *$ and $* * *$ denote significance at the $10 \%, 5 \%$ and $1 \%$ percent level respectively. Fp reports the $p$-value corresponding to the F-statistic and shows the overall significance of the regression model. 
Table 3: Regressions of price on categories based on KLD strengths and concerns

\begin{tabular}{|c|c|c|c|c|c|c|}
\hline Variable & Community & Diversity & Employee & Environment & Product & Overall \\
\hline BVPS & $\begin{array}{l}0.893 * * * \\
(9.94)\end{array}$ & $\begin{array}{l}0.895 * * * \\
(9.86)\end{array}$ & $\begin{array}{l}0.896 * * * \\
(9.90)\end{array}$ & $\begin{array}{l}0.893^{* * *} \\
(9.87)\end{array}$ & $\begin{array}{l}0.893 * * * \\
(9.90)\end{array}$ & $\begin{array}{l}0.894^{* * *} \\
(9.89)\end{array}$ \\
\hline NIPS & $\begin{array}{l}4.505 * * * \\
(6.28)\end{array}$ & $\begin{array}{l}4.495^{* * *} \\
(6.29)\end{array}$ & $\begin{array}{l}4.489 * * * \\
(6.28)\end{array}$ & $\begin{array}{l}4.501^{* * *} \\
(6.30)\end{array}$ & $\begin{array}{l}4.495 * * * \\
(6.27)\end{array}$ & $\begin{array}{l}4.498^{* * *} \\
(6.30)\end{array}$ \\
\hline LTDTA & $\begin{array}{l}-3.862 \\
(-1.40)\end{array}$ & $\begin{array}{l}-3.629 \\
(-1.30)\end{array}$ & $\begin{array}{l}-3.601 \\
(-1.29)\end{array}$ & $\begin{array}{l}-3.976 \\
(-1.40)\end{array}$ & $\begin{array}{l}-3.857 \\
(-1.37)\end{array}$ & $\begin{array}{l}-3.593 \\
(-1.30)\end{array}$ \\
\hline LOGass & $\begin{array}{l}1.575^{* * *} \\
(4.68)\end{array}$ & $\begin{array}{l}1.386^{* * *} \\
(4.04)\end{array}$ & $\begin{array}{l}1.441^{* * *} \\
(4.15)\end{array}$ & $\begin{array}{l}1.608 * * * \\
(4.57)\end{array}$ & $\begin{array}{l}1.588^{* * *} \\
(4.00)\end{array}$ & $\begin{array}{l}1.490^{* * *} \\
(4.19)\end{array}$ \\
\hline RDPS & $\begin{array}{l}2.522^{* *} \\
(2.20)\end{array}$ & $\begin{array}{l}2.495^{* *} \\
(2.18)\end{array}$ & $\begin{array}{l}2.469 * * \\
(2.18)\end{array}$ & $\begin{array}{l}2.569 * * \\
(2.26)\end{array}$ & $\begin{array}{l}2.442^{* *} \\
(2.12)\end{array}$ & $\begin{array}{l}2.494^{* *} \\
(2.18)\end{array}$ \\
\hline comgrn & $\begin{array}{l}0.545 \\
(0.50)\end{array}$ & & & & & \\
\hline comtox & $\begin{array}{l}-2.064^{* *} \\
(-2.00)\end{array}$ & & & & & \\
\hline divgrn & & $\begin{array}{l}1.517^{* *} \\
(2.16)\end{array}$ & & & & \\
\hline divtox & & $\begin{array}{l}-0.911 \\
(-1.26)\end{array}$ & & & & \\
\hline empgrn & & & $\begin{array}{l}2.222^{* * *} \\
(2.67)\end{array}$ & & & \\
\hline emptox & & & $\begin{array}{l}-1.678^{* *} \\
(-2.03)\end{array}$ & & & \\
\hline envgrn & & & & $\begin{array}{l}0.812 \\
(0.78)\end{array}$ & & \\
\hline envtox & & & & $\begin{array}{l}-1.705^{*} \\
(-1.96)\end{array}$ & & \\
\hline progrn & & & & & $\begin{array}{l}7.314^{* *} \\
(2.40)\end{array}$ & \\
\hline protox & & & & & $\begin{array}{l}-1.100 \\
(-1.22)\end{array}$ & \\
\hline overgrn & & & & & & $\begin{array}{l}1.927^{* * *} \\
(2.93)\end{array}$ \\
\hline overtox & & & & & & $\begin{array}{l}-1.012^{* *} \\
(-2.11)\end{array}$ \\
\hline Intercept & $\begin{array}{l}10.079 \\
(1.21)\end{array}$ & $\begin{array}{l}11.305 \\
(1.44)\end{array}$ & $\begin{array}{l}11.443 \\
(1.45)\end{array}$ & $\begin{array}{l}10.262 \\
(1.25)\end{array}$ & $\begin{array}{l}10.416 \\
(1.33)\end{array}$ & $\begin{array}{l}10.967 \\
(1.36)\end{array}$ \\
\hline Industry Controls & yes & yes & yes & yes & yes & yes \\
\hline $\mathbf{N}$ & 16758 & 16758 & 16758 & 16758 & 16758 & 16758 \\
\hline $\mathrm{Fp}$ & 0.000 & 0.000 & 0.000 & 0.000 & 0.000 & 0.000 \\
\hline $\mathbf{R 2}$ & 0.710 & 0.710 & 0.711 & 0.710 & 0.711 & 0.710 \\
\hline
\end{tabular}

The Table shows the result of regressing June price of year $t$ on net book value (BVPS) and net income (NIPS) for financial year ended t-1, together with Research and Development Expenditures (RDPS), Leverage - ratio of long-term debt to total assets (LTDTA), log Total Assets (LOGass) and dummy variables for the KLD strength and concern indicators defined using the Fernando et al. (2010) classifications for each CSR indicator. For each CSR indicator firms are classified as 'Green' (grn) if they have only strengths, and 'Toxic' (tox) if they have only weaknesses. t-statistics computed using cluster robust standard errors from the two-way cluster approach of Petersen (2009) are shown in parentheses.. All regressions include dummy variables reflecting membership of the Fama-French 48 industry groups. $*, * *$ and $* * *$ denote significance at the $10 \%, 5 \%$ and $1 \%$ percent level respectively. $F_{p}$ reports the $p$-value corresponding to the F-statistic and shows the overall significance of the regression model. 
Table 4: Realised Return Regressions for portfolios of 'Green' stocks and 'Toxic' stocks for each CSR Indicator

\begin{tabular}{|c|c|c|c|c|c|c|}
\hline \multicolumn{7}{|c|}{ Panel A : equally weighted 'Green' stocks portfolio } \\
\hline \multirow{3}{*}{$\begin{array}{l}\text { Varlable } \\
\text { rm-rf }\end{array}$} & Community & Diversity & Employee & Environment & Product & Overall \\
\hline & $\begin{array}{l}1.014^{* * *} \\
(2971)\end{array}$ & $1.132 * * *$ & $1.124 * * *$ & $1.040^{* * *}$ & $1.121^{* * *}$ & $1.114^{* * *}$ \\
\hline & & & & & & $(32.72)$ \\
\hline smb & $\begin{array}{l}0.064 \\
(1.48)\end{array}$ & $\begin{array}{l}0.132 * * * \\
(2.70)\end{array}$ & $\begin{array}{l}0.153^{* * *} \\
(2.83)\end{array}$ & $\begin{array}{l}0.208 * * * \\
(3.21)\end{array}$ & $\begin{array}{l}0.236^{* * *} \\
(3.54)\end{array}$ & $\begin{array}{l}0.175^{* * *} \\
(3.46)\end{array}$ \\
\hline hml & $\begin{array}{l}0.567^{* * * *} \\
(13.03)\end{array}$ & $\begin{array}{l}0.458^{* * *} \\
(8.70)\end{array}$ & $\begin{array}{l}0.425^{* * *} \\
(8.58)\end{array}$ & $\begin{array}{l}0.496 * * * \\
(7.39)\end{array}$ & $\begin{array}{l}0.355^{* * *} \\
(6.12)\end{array}$ & $\begin{array}{l}0.462^{* * *} \\
(9.31)\end{array}$ \\
\hline Intercept & $\begin{array}{l}-0.002 \\
(-0.02)\end{array}$ & $\begin{array}{l}-0.028 \\
(-0.25)\end{array}$ & $\begin{array}{l}0.011 \\
(0.10)\end{array}$ & $\begin{array}{l}-0.035 \\
(-0.25)\end{array}$ & $\begin{array}{l}0.080 \\
(0.60)\end{array}$ & $\begin{array}{l}-0.023 \\
(-0.22)\end{array}$ \\
\hline $\mathbf{F}_{\mathbf{p}}$ & 0.000 & 0.000 & 0.000 & 0.000 & 0.000 & 0.000 \\
\hline $\mathbf{R}^{2}$ & 0.881 & 0.900 & 0.914 & 0.841 & 0.866 & 0.903 \\
\hline \multicolumn{7}{|c|}{ Panel B : equally weighted 'Toxic' stocks portfolio } \\
\hline $\begin{array}{l}\text { Variable } \\
\text { rm-rf }\end{array}$ & $\begin{array}{l}\text { Community } \\
1.052^{* * *} \\
(24.67)\end{array}$ & $\begin{array}{l}\text { Diversity } \\
1.183^{* * *} \\
(27.89)\end{array}$ & $\begin{array}{l}\text { Employee } \\
1.212^{* * *} \\
(25.32)\end{array}$ & $\begin{array}{l}\text { Environment } \\
1.101^{* * *} \\
(22.56)\end{array}$ & $\begin{array}{l}\text { Product } \\
1.042^{* * *} \\
(29.45)\end{array}$ & $\begin{array}{l}\text { Overall } \\
1.146^{* * *} \\
(28.70)\end{array}$ \\
\hline smb & $\begin{array}{l}0.073 \\
(0.98)\end{array}$ & $\begin{array}{l}0.304^{* * *} \\
(4.01)\end{array}$ & $\begin{array}{l}0.212^{* * * *} \\
(2.93)\end{array}$ & $\begin{array}{l}0.065 \\
(1.02)\end{array}$ & $\begin{array}{l}0.014 \\
(0.28)\end{array}$ & $\begin{array}{l}0.186^{* * * *} \\
(2.74)\end{array}$ \\
\hline hml & $\begin{array}{l}0.700 * * * \\
(9.64)\end{array}$ & $\begin{array}{l}0.479 * * * \\
(6.58)\end{array}$ & $\begin{array}{l}0.529 * * * \\
(6.72)\end{array}$ & $\begin{array}{l}0.701^{* * *} \\
(9.06)\end{array}$ & $\begin{array}{l}0.572^{* * *} \\
(9.96)\end{array}$ & $\begin{array}{l}0.609 * * * \\
(8.87)\end{array}$ \\
\hline Intercept & $\begin{array}{l}-0.116 \\
(-0.63)\end{array}$ & $\begin{array}{l}-0.066 \\
(-0.42)\end{array}$ & $\begin{array}{l}-0.144 \\
(-0.90)\end{array}$ & $\begin{array}{l}-0.129 \\
(-0.84)\end{array}$ & $\begin{array}{l}0.056 \\
(0.47)\end{array}$ & $\begin{array}{l}-0.165 \\
(-1.19)\end{array}$ \\
\hline $\mathbf{F}_{\mathbf{p}}$ & 0.000 & 0.000 & 0.000 & 0.000 & 0.000 & 0.000 \\
\hline $\mathbf{R}^{\mathbf{2}}$ & 0.767 & 0.853 & 0.848 & 0.833 & 0.884 & 0.871 \\
\hline \multicolumn{7}{|c|}{ Panel C: equally weighted portfolios long in 'Green' stocks and short in 'Toxic' stocks } \\
\hline $\begin{array}{l}\text { Variable } \\
\text { rm-rf }\end{array}$ & $\begin{array}{l}\text { Community } \\
-0.039 \\
(-0.93)\end{array}$ & $\begin{array}{l}\text { Diversity } \\
-0.051^{* *} \\
(-1.99)\end{array}$ & $\begin{array}{l}\text { Employee } \\
-0.088^{* * *} \\
(-2.84)\end{array}$ & $\begin{array}{l}\text { Environment } \\
-0.061^{*} \\
(-1.81)\end{array}$ & $\begin{array}{l}\text { Product } \\
0.079 * * \\
(2.46)\end{array}$ & $\begin{array}{l}\text { Overall } \\
-0.032 \\
(-1.28)\end{array}$ \\
\hline smb & $\begin{array}{l}-0.009 \\
(-0.18)\end{array}$ & $\begin{array}{l}-0.171 * * * \\
(-3.70)\end{array}$ & $\begin{array}{l}-0.059 \\
(-1.41)\end{array}$ & $\begin{array}{l}0.143^{* * *} \\
(3.46)\end{array}$ & $\begin{array}{l}0.222^{* * *} \\
(5.13)\end{array}$ & $\begin{array}{l}-0.011 \\
(-0.31)\end{array}$ \\
\hline hml & $\begin{array}{l}-0.134^{* *} \\
(-2.12)\end{array}$ & $\begin{array}{l}-0.021 \\
(-0.50)\end{array}$ & $\begin{array}{l}-0.105^{* *} \\
(-2.08)\end{array}$ & $\begin{array}{l}-0.205^{* * *} \\
(-4.55)\end{array}$ & $\begin{array}{l}-0.216^{* * *} \\
(-4.86)\end{array}$ & $\begin{array}{l}-0.147^{* * *} \\
(-3.70)\end{array}$ \\
\hline Intercept & $\begin{array}{l}0.114 \\
(0.70)\end{array}$ & $\begin{array}{l}0.038 \\
(0.32)\end{array}$ & $\begin{array}{l}0.155 \\
(1.40)\end{array}$ & $\begin{array}{l}0.094 \\
(0.75)\end{array}$ & $\begin{array}{l}0.025 \\
(0.20)\end{array}$ & $\begin{array}{l}0.141 \\
(1.54)\end{array}$ \\
\hline $\mathbf{F}_{\mathbf{p}}$ & 0.200 & 0.000 & 0.005 & 0.000 & 0.000 & 0.004 \\
\hline \multirow{2}{*}{$\frac{\mathbf{R}^{\mathbf{2}}}{\text { Par }}$} & 0.037 & 0.134 & 0.085 & 0.214 & 0.369 & 0.124 \\
\hline & Istry adjusted & ually weigh & nortfoli & g in 'Green' sto & $s$ and short $i$ & Toxic' stocks \\
\hline $\begin{array}{l}\text { Variable } \\
\text { rm-rf }\end{array}$ & $\begin{array}{l}\text { Community } \\
-0.057^{* *} \\
(-2.00)\end{array}$ & $\begin{array}{l}\text { Diversity } \\
0.000 \\
(0.01)\end{array}$ & $\begin{array}{l}\text { Employee } \\
-0.038 \\
(-1.58)\end{array}$ & $\begin{array}{l}\text { Environment } \\
-0.083^{*} * * \\
(-2.70)\end{array}$ & $\begin{array}{l}\text { Product } \\
-0.047 \\
(-1.64)\end{array}$ & $\begin{array}{l}\text { Overall } \\
-0.024 \\
(-1.26)\end{array}$ \\
\hline smb & $\begin{array}{l}-0.098^{* *} \\
(-2.47)\end{array}$ & $\begin{array}{l}-0.174 * * * \\
(-4.75)\end{array}$ & $\begin{array}{l}-0.067^{*} \\
(-1.89)\end{array}$ & $\begin{array}{l}0.036 \\
(0.88)\end{array}$ & $\begin{array}{l}0.082^{* *} \\
(2.13)\end{array}$ & $\begin{array}{l}-0.052^{*} \\
(-1.97)\end{array}$ \\
\hline hml & $\begin{array}{l}0.018 \\
(0.40)\end{array}$ & $\begin{array}{l}0.040 \\
(1.13)\end{array}$ & $\begin{array}{l}-0.065 \\
(-1.52)\end{array}$ & $\begin{array}{l}-0.057 \\
(-1.49)\end{array}$ & $\begin{array}{l}-0.125^{* * *} \\
(-2.69)\end{array}$ & $\begin{array}{l}-0.036 \\
(-1.25)\end{array}$ \\
\hline Intercept & $\begin{array}{l}0.087 \\
(0.72)\end{array}$ & $\begin{array}{l}0.025 \\
(0.24)\end{array}$ & $\begin{array}{l}0.116 \\
(1.15)\end{array}$ & $\begin{array}{l}0.113 \\
(1.04)\end{array}$ & $\begin{array}{l}0.092 \\
(0.82)\end{array}$ & $\begin{array}{l}0.135^{*} \\
(1.84)\end{array}$ \\
\hline $\mathbf{F}_{\mathbf{p}}$ & 0.003 & 0.000 & 0.033 & 0.025 & 0.000 & 0.070 \\
\hline $\mathbf{R}^{\mathbf{2}}$ & 0.079 & 0.175 & 0.045 & 0.054 & 0.102 & 0.041 \\
\hline
\end{tabular}

The table shows the results of the regression of the returns to a portfolio of stocks formed on the basis of their overall CSR strengths and concerns. 'Green' stocks are those with only strengths and no concerns; 'Toxic' stocks are those with only concerns and no strengths. Panel A, Panel B and Panel $C$ shows the result of running simple stock portfolios minus the risk free rate as the dependent variable on the Fama-French three-factor model: $R_{p t}-R_{f t}=\alpha_{p}+\beta_{p}\left(R_{m t}-R_{f t}\right)+s_{p} S M B_{t}+h_{p} H_{L}+\varepsilon_{p t}^{1} \quad l n$ Panel $A$, and Panel $B$ the dependent variables are the returns on a portfolio long in green stocks, and long in toxic stocks respectively, minus the risk free rate. In Panel $\mathrm{C}$, the dependent variable is the return on a portfolio long in green and short in toxic stocks. Panel $D$ shows the result of running industry adjusted portfolio returns on an industry-adjusted three factor model: $\mathrm{R}_{\mathrm{pt}}-\mathrm{R}_{\mathrm{pjt}}=\alpha_{\mathrm{p}}+\beta_{\mathrm{p}}\left(\mathrm{R}_{\mathrm{mt}}-\mathrm{R}_{\mathrm{ft}}\right)+\mathrm{s}_{\mathrm{p}} \mathrm{SMB}_{\mathrm{t}}+\mathrm{h}_{\mathrm{p}} \mathrm{HML}_{\mathrm{t}}+\varepsilon_{\mathrm{pt}}^{2}$

in green stocks and short in toxic stocks. In all the panels, the t-statistics are in parentheses. $* * *$ and *** denote significance at the $10 \%, 5 \%$ and $1 \%$ percent level respectively. Fp reports the p-value corresponding to the F-statistic and shows the overall significance of the regression model. 
Table 5: Differences in Analysts' one year ahead Return on Equity Forecasts

\begin{tabular}{|c|c|c|c|c|c|c|}
\hline Variable & Community & Diversity & Employee & Environment & Product & Overall \\
\hline Green & $\begin{array}{l}0.015^{* *} \\
(2.28)\end{array}$ & $\begin{array}{l}0.016^{* * *} \\
(3.52)\end{array}$ & $\begin{array}{l}0.015^{* * *} \\
(3.34)\end{array}$ & $\begin{array}{l}-0.013^{* *} \\
(-1.99)\end{array}$ & $\begin{array}{l}0.011 \\
(1.18)\end{array}$ & $\begin{array}{l}0.008^{*} \\
(1.79)\end{array}$ \\
\hline Toxic & $\begin{array}{l}0.018^{* * * *} \\
(3.27)\end{array}$ & $\begin{array}{l}0.003 \\
(0.83)\end{array}$ & $\begin{array}{l}0.004 \\
(0.97)\end{array}$ & $\begin{array}{l}0.004 \\
(0.87)\end{array}$ & $\begin{array}{l}0.016^{* * * *} \\
(4.09)\end{array}$ & $\begin{array}{l}0.009 * * \\
(1.96)\end{array}$ \\
\hline Grey & $\begin{array}{l}0.036^{* * *} \\
(4.01)\end{array}$ & $\begin{array}{l}0.031^{* * *} \\
(3.45)\end{array}$ & $\begin{array}{l}0.020 * * * \\
(3.02)\end{array}$ & $\begin{array}{l}0.013^{*} \\
(1.66)\end{array}$ & $\begin{array}{l}0.048^{* * *} \\
(5.61)\end{array}$ & $\begin{array}{l}0.021^{* * *} \\
(4.41)\end{array}$ \\
\hline LOGass & $\begin{array}{l}0.001 \\
(0.96)\end{array}$ & $\begin{array}{l}0.002 \\
(1.08)\end{array}$ & $\begin{array}{l}0.002 \\
(1.48)\end{array}$ & $\begin{array}{l}0.003^{* *} \\
(2.12)\end{array}$ & $\begin{array}{l}0.001 \\
(0.85)\end{array}$ & $\begin{array}{l}0.002 \\
(1.24)\end{array}$ \\
\hline LTDTA & $\begin{array}{l}0.024^{*} \\
(1.75)\end{array}$ & $\begin{array}{l}0.023^{*} \\
(1.71)\end{array}$ & $\begin{array}{l}0.022^{*} \\
(1.67)\end{array}$ & $\begin{array}{l}0.019 \\
(1.47)\end{array}$ & $\begin{array}{l}0.021 \\
(1.60)\end{array}$ & $\begin{array}{l}0.022 \\
(1.59)\end{array}$ \\
\hline RDPS & $\begin{array}{l}-0.005 \\
(-1.55)\end{array}$ & $\begin{array}{l}-0.005 \\
(-1.57)\end{array}$ & $\begin{array}{l}-0.005 \\
(-1.59)\end{array}$ & $\begin{array}{l}-0.005 \\
(-1.53)\end{array}$ & $\begin{array}{l}-0.005^{*} \\
(-1.74)\end{array}$ & $\begin{array}{l}-0.004 \\
(-1.51)\end{array}$ \\
\hline Intercept & $\begin{array}{l}0.124^{* * *} \\
(2.82)\end{array}$ & $\begin{array}{l}0.122^{* * *} \\
(2.78)\end{array}$ & $\begin{array}{l}0.113^{* *} \\
(2.41)\end{array}$ & $\begin{array}{l}0.122^{* * *} \\
(2.90)\end{array}$ & $\begin{array}{l}0.128 * * * \\
(2.91)\end{array}$ & $\begin{array}{l}0.112^{* *} \\
(2.44)\end{array}$ \\
\hline Industry Controls & yes & yes & yes & yes & yes & yes \\
\hline Green-Toxic & -0.003 & $0.013^{* * *}$ & $0.011^{*}$ & $-0.017 * *$ & -0.004 & $-0.001 *$ \\
\hline Pval of diff & 0.724 & 0.003 & 0.056 & 0.02 & 0.656 & 0.06 \\
\hline$F_{p}$ & 0.000 & 0.000 & 0.000 & 0.000 & 0.000 & 0.000 \\
\hline $\mathbf{R}^{2}$ & 0.055 & 0.057 & 0.054 & 0.053 & 0.057 & 0.055 \\
\hline $\mathbf{N}$ & 13089 & 13089 & 13089 & 13089 & 13089 & 13089 \\
\hline Green-Toxic (NC) & 0.000 & $0.018 * * *$ & $0.014^{* * *}$ & $-0.016 * * *$ & $-0.009 *$ & 0.002 \\
\hline Pval of diff & 0.914 & 0.000 & 0.000 & 0.000 & 0.065 & 0.500 \\
\hline Green-Toxic (S) & -0.007 & 0.002 & 0.006 & -0.012 & 0.001 & -0.004 \\
\hline Pval of diff & 0.431 & 0.61 & 0.293 & 0.100 & 0.901 & 0.345 \\
\hline \multicolumn{7}{|c|}{ Panel B: Forecast ROE 1 year ahead by KLD strengths and concerns } \\
\hline Variable & Community & Diversity & Employee & Environment & Product & Overall \\
\hline Strength & $\begin{array}{l}0.009 * * \\
(2.37)\end{array}$ & $\begin{array}{l}0.014^{* * *} \\
(5.90)\end{array}$ & $\begin{array}{l}0.011^{* * *} \\
(4.08)\end{array}$ & $\begin{array}{l}0.003 \\
(0.75)\end{array}$ & $\begin{array}{l}0.020^{* *} \\
(2.57)\end{array}$ & $\begin{array}{l}0.007^{* * *} \\
(5.95)\end{array}$ \\
\hline Concern & $\begin{array}{l}0.018^{* * *} \\
(3.35)\end{array}$ & $\begin{array}{l}0.005 \\
(1.50)\end{array}$ & $\begin{array}{l}0.005 \\
(1.58)\end{array}$ & $\begin{array}{l}0.004 \\
(1.64)\end{array}$ & $\begin{array}{l}0.015^{* * *} \\
(5.64)\end{array}$ & $\begin{array}{l}0.004^{* * *} \\
(2.93)\end{array}$ \\
\hline LOGass & $\begin{array}{l}0.001 \\
(0.91)\end{array}$ & $\begin{array}{l}0.000 \\
(-0.26)\end{array}$ & $\begin{array}{l}0.002 \\
(1.23)\end{array}$ & $\begin{array}{l}0.003 * \\
(1.93)\end{array}$ & $\begin{array}{l}0.000 \\
(0.39)\end{array}$ & $\begin{array}{l}-0.003 \\
(-1.44)\end{array}$ \\
\hline LTDTA & $\begin{array}{l}0.024^{*} \\
(1.77)\end{array}$ & $\begin{array}{l}0.026^{* *} \\
(1.99)\end{array}$ & $\begin{array}{l}0.023^{*} \\
(1.72)\end{array}$ & $\begin{array}{l}0.02 \\
(1.49)\end{array}$ & $\begin{array}{l}0.024 * \\
(1.77)\end{array}$ & $\begin{array}{l}0.031^{* *} \\
(2.40)\end{array}$ \\
\hline RDPS & $\begin{array}{l}-0.005 \\
(-1.55)\end{array}$ & $\begin{array}{l}-0.005^{*} \\
(-1.68)\end{array}$ & $\begin{array}{l}-0.005 \\
(-1.59)\end{array}$ & $\begin{array}{l}-0.005 \\
(-1.58)\end{array}$ & $\begin{array}{l}-0.005^{*} \\
(-1.76)\end{array}$ & $\begin{array}{l}-0.006 * * \\
(-2.02)\end{array}$ \\
\hline Intercept & $\begin{array}{l}0.125 * * * \\
(2.85)\end{array}$ & $\begin{array}{l}0.136 * * * \\
(3.18)\end{array}$ & $\begin{array}{l}0.114^{* *} \\
(2.44)\end{array}$ & $\begin{array}{l}0.116 * * * \\
(2.60)\end{array}$ & $\begin{array}{l}0.130^{* * *} \\
(2.92)\end{array}$ & $\begin{array}{l}0.139 * * * \\
(2.97)\end{array}$ \\
\hline Industry Controls & yes & yes & yes & yes & yes & yes \\
\hline $\mathbf{F}_{\mathrm{p}}$ & 0.000 & 0.000 & 0.000 & 0.000 & 0.000 & 0.000 \\
\hline $\mathbf{R}^{2}$ & 0.056 & 0.066 & 0.056 & 0.051 & 0.06 & 0.068 \\
\hline $\mathbf{N}$ & 13089 & 13089 & 13089 & 13089 & 13089 & 13089 \\
\hline
\end{tabular}

The table shows the differences in analyst's one year ahead forecasted Return on Equity (ROE) by portfolios formed on the basis of strengths and concerns across CSR dimensions. The forecasted return on equity for period $t+\tau$ (where $\tau$ is 1 ) is computed as forecast EPS for period $t+\tau$ / book value of equity for period $t+\tau-1$. In Panel A portfolios are formed on the basis of firms with only positive CSR scores in that dimension and no negative scores in that dimension ('Green'), firms with only negative CSR scores in that dimension and no positive scores in that dimension ('Toxic'), together with firms with no scores ('Neutral') and mixed scores ('Gray') in that dimension. In Panel A Green-Toxic (NC) shows the results of a t-test (without controls variables) for difference in mean analyst forecasted one year ahead ROE between 'Green' and 'Toxic' groups. Green-Toxic(S) shows the results where LOGsal (natural logarithm of sales) is used as a control for firm size instead of LOGass (Natural logarithm of Total Assets). Green-Toxic (NC) shows the difference between portfolios of 'Green' and 'Toxic' stocks without any control variables. For Green-Toxic (NC), the difference in mean is computed using a t-test for difference in means. $F_{p}$ reports the $p$-value corresponding to the F-statistic and shows the overall significance of the regression model. In Panel B portfolios are formed on the basis of number of CSR strengths and concerns in that dimension. LTDTA is Leverage, measured as the ratio of Long-term Debt to Total Assets (LTDTA), LOGass is the natural log 
of Total Assets and RDPS is the Research and Development expenditure per share. t-statistics computed using cluster robust standard errors from the two-way cluster approach of Petersen (2009) are shown in parentheses. ${ }^{*}, * *$ and ${ }^{* * *}$ denote significance at the $10 \%, 5 \%$ and $1 \%$ percent level respectively. 
Table 6. Differences in Analysts' two year ahead Return on Equity Forecasts

\begin{tabular}{lllllll}
\hline Panel A: Forecast ROE two years ahead by & categories based on KLD strengths and concerns & \\
\hline Variable & Community & Diversity & Employee & Environment & Product & Overall \\
green & $0.012^{* *}$ & $0.017^{* * *}$ & $0.013^{* * *}$ & $-0.014^{* *}$ & 0.006 & $0.007^{* *}$ \\
& $(2.14)$ & $(4.63)$ & $(3.42)$ & $(-2.47)$ & $(0.78)$ & $(2.11)$ \\
toxic & $0.017^{* * *}$ & 0.004 & $0.006^{* *}$ & 0.004 & $0.015^{* * *}$ & $0.009^{* * *}$ \\
& $(3.74)$ & $(1.05)$ & $(2.06)$ & $(0.91)$ & $(4.33)$ & $(2.75)$ \\
grey & $0.037^{* * *}$ & $0.032^{* * *}$ & $0.021^{* * *}$ & $0.013^{* *}$ & $0.042^{* * *}$ & $0.020^{* * *}$ \\
& $(4.58)$ & $(4.33)$ & $(3.77)$ & $(2.14)$ & $(5.69)$ & $(5.05)$ \\
LOGass & -0.002 & -0.002 & -0.001 & -0.000 & -0.002 & -0.001 \\
& $(-1.26)$ & $(-1.09)$ & $(-0.65)$ & $(-0.02)$ & $(-1.17)$ & $(-0.88)$ \\
LTDTA & $0.035^{* * *}$ & $0.035^{* * *}$ & $0.033^{* * *}$ & $0.031^{* * *}$ & $0.033^{* * *}$ & $0.033^{* * *}$ \\
& $(3.45)$ & $(3.47)$ & $(3.39)$ & $(3.16)$ & $(3.26)$ & $(3.30)$ \\
RDPS & $-0.006^{* *}$ & $-0.006^{* *}$ & $-0.006^{* *}$ & $-0.006^{* *}$ & $-0.006^{* *}$ & $-0.005^{* *}$ \\
& $(-2.17)$ & $(-2.27)$ & $(-2.22)$ & $(-2.17)$ & $(-2.38)$ & $(-2.14)$ \\
Intercept & $0.143^{* * *}$ & $0.142^{* * *}$ & $0.131^{* * *}$ & $0.142^{* * *}$ & $0.146^{* * *}$ & $0.132^{* * *}$ \\
& $(4.14)$ & $(4.21)$ & $(3.57)$ & $(4.47)$ & $(4.26)$ & $(3.69)$ \\
Industry Controls & yes & yes & yes & yes & yes & yes \\
Green-Toxic & -0.005 & $0.013^{* * *}$ & 0.007 & $-0.018^{* * *}$ & -0.008 & -0.002 \\
Pval of diff & 0.557 & 0.000 & 0.137 & 0.004 & 0.360 & 0.570 \\
N & 13089 & 13089 & 13089 & 13089 & 13089 & 13089 \\
Fp & 0.000 & 0.000 & 0.000 & 0.000 & 0.000 & 0.000 \\
R & 0.064 & 0.068 & 0.063 & 0.061 & 0.066 & 0.064 \\
Green-Toxic (S) & -0.007 & 0.005 & 0.003 & $-0.014^{* *}$ & -0.004 & -0.005 \\
Pval of diff & 0.326 & 0.175 & 0.548 & 0.020 & 0.680 & 0.172 \\
Green-Toxic (NC) & -0.003 & $0.011^{* * *}$ & $0.006^{* * *}$ & $-0.014^{* * *}$ & -0.006 & -0.003 \\
Pval of diff & 0.413 & 0.000 & 0.014 & 0.000 & 0.118 & 0.164 \\
\hline
\end{tabular}

\begin{tabular}{|c|c|c|c|c|c|c|}
\hline \multicolumn{7}{|c|}{ Panel B: Forecast ROE 2 year ahead by KLD strengths and concerns } \\
\hline Variable & Community & Diversity & Employee & Environment & Product & Overall \\
\hline \multirow[t]{2}{*}{ Strength } & $0.009 * * *$ & $0.014 * * *$ & $0.010 * * *$ & 0.003 & $0.014 * *$ & $0.006 * * *$ \\
\hline & $(2.68)$ & (7.11) & $(4.51)$ & $(0.76)$ & $(2.25)$ & $(7.30)$ \\
\hline \multirow[t]{2}{*}{ Concern } & $0.017 * * *$ & 0.005 & $0.007^{* * *}$ & $0.005^{* * *}$ & $0.015^{* * *}$ & $0.005^{* * *}$ \\
\hline & $(3.90)$ & $(1.63)$ & $(2.79)$ & $(2.59)$ & $(6.26)$ & $(3.98)$ \\
\hline \multirow[t]{2}{*}{ LOGass } & -0.002 & $-0.004 * *$ & -0.001 & -0.000 & $-0.002^{*}$ & $-0.006 * * *$ \\
\hline & $(-1.33)$ & $(-2.44)$ & $(-0.91)$ & $(-0.29)$ & $(-1.77)$ & $(-3.66)$ \\
\hline \multirow[t]{2}{*}{ LTDTA } & $0.035 * * *$ & $0.038 * *$ & $0.034 * * *$ & $0.032 * * *$ & $0.035 * * *$ & $0.043 * * *$ \\
\hline & $(3.51)$ & $(3.82)$ & $(3.48)$ & $(3.20)$ & $(3.46)$ & $(4.36)$ \\
\hline \multirow[t]{2}{*}{ RDPS } & $-0.006 * *$ & $-0.006 * *$ & $-0.006 * *$ & $-0.006 * *$ & $-0.006 * *$ & $-0.007 * * *$ \\
\hline & $(-2.20)$ & $(-2.42)$ & $(-2.24)$ & $(-2.27)$ & $(-2.38)$ & $(-2.75)$ \\
\hline \multirow[t]{2}{*}{ Intercept } & $0.145^{* * *}$ & $0.156^{* * *}$ & $0.132 * * *$ & $0.137 * * *$ & $0.148 * * *$ & $0.157^{* * *}$ \\
\hline & $(4.22)$ & $(4.73)$ & (3.59) & (3.93) & $(4.22)$ & $(4.23)$ \\
\hline Industry Controls & yes & yes & yes & yes & yes & yes \\
\hline $\mathbf{N}$ & 13089 & 13089 & 13089 & 13089 & 13089 & 13089 \\
\hline $\mathrm{Fp}$ & 0.000 & 0.000 & 0.000 & 0.000 & 0.000 & 0.000 \\
\hline $\mathbf{R}^{2}$ & 0.065 & 0.080 & 0.066 & 0.059 & 0.069 & 0.083 \\
\hline
\end{tabular}

The table shows the differences in analyst's two year ahead forecasted Return on Equity (ROE) by portfolios formed on the basis of strengths and concerns across CSR dimensions. The forecasted return on equity for period $t+\tau$ (where $\tau$ is 2 ) is computed as forecast EPS for period $t+\tau$ / book value of equity for period $t+\tau-1$. In Panel A portfolios are formed on the basis of firms with only positive CSR scores in that dimension and no negative scores in that dimension ('Green'), firms with only negative CSR scores in that dimension and no positive scores in that dimension ('Toxic'), together with firms with no scores ('Neutral') and mixed scores ('Gray') in that dimension. In Panel A Green-Toxic (NC) shows the results of a t-test (without controls variables) for difference in mean analyst forecasted one year ahead ROE between 'Green' and 'Toxic' groups. Green-Toxic(S) shows the results where LOGsales is used as a control for firm size instead of LOGass. GreenToxic(NC) shows the difference between portfolios of 'Green' and 'Toxic' stocks without any control variables. In GreenToxic(NC), the difference in mean is computed using a t-test for difference in means. $F_{p}$ reports the $p$-value corresponding to the F-statistic and shows the overall significance of the regression model. In Panel B portfolios are formed on the basis 
of number of CSR strengths and concerns in that dimension. LTDTA is Leverage, measured as the ratio of Long-term Debt to Total Assets (LTDTA), LOGass is the natural log of Total Assets and RDPS is the Research and Development expenditure per share. t-statistics computed using cluster robust standard errors from the two-way cluster approach of Petersen (2009) are shown in parentheses. ${ }^{*}, * *$ and ${ }^{* * *}$ denote significance at the $10 \%, 5 \%$ and $1 \%$ percent level respectively. 
Table 7: Implied Long term Growth Estimates by CSR Category

\begin{tabular}{lllllll}
\hline Panel A: Implied Long-term Growth by categories based on KLD strengths and concerns \\
\hline Variable & Community & Diversity & Employee & Environment & Product & Overall \\
Green & $0.0125^{*}$ & 0.004 & 0.003 & $0.012^{*}$ & $0.025^{* * *}$ & $0.0185^{* * *}$ \\
& $(1.65)$ & $(0.83)$ & $(0.67)$ & $(1.74)$ & $(3.78)$ & $(4.28)$ \\
Toxic & $-0.0120^{*}$ & -0.007 & -0.004 & -0.011 & -0.005 & 0.001 \\
& $(-1.76)$ & $(-1.18)$ & $(-0.63)$ & $(-1.54)$ & $(-0.81)$ & $(0.16)$ \\
Grey & -0.013 & -0.013 & -0.009 & -0.012 & 0.011 & 0.007 \\
& $(-1.53)$ & $(-1.45)$ & $(-0.81)$ & $(-1.57)$ & -1.5 & $(1.07)$ \\
LOGass & -0.003 & -0.003 & -0.002 & -0.002 & -0.003 & -0.003 \\
& $(-1.28)$ & $(-1.26)$ & $(-0.93)$ & $(-0.80)$ & $(-1.09)$ & $(-1.34)$ \\
LTDTA & $-0.054^{* * *}$ & $-0.054^{* * *}$ & $-0.055^{* * *}$ & $-0.055^{* * *}$ & $-0.054^{* * *}$ & $-0.052^{* * *}$ \\
& $(-6.17)$ & $(-5.67)$ & $(-5.66)$ & $(-6.03)$ & $(-5.83)$ & $(-5.53)$ \\
RDPS & 0.001 & 0.001 & 0.001 & 0.001 & 0.001 & 0.001 \\
& -0.31 & -0.41 & -0.49 & -0.63 & -0.37 & $(0.31)$ \\
Intercept & -0.038 & -0.032 & -0.037 & -0.047 & -0.038 & -0.038 \\
& $(-0.59)$ & $(-0.50)$ & $(-0.60)$ & $(-0.71)$ & $(-0.59)$ & $(-0.60)$ \\
Industry Controls & yes & yes & yes & yes & yes & yes \\
Green-Toxic & $0.024 *$ & $0.014^{* * *}$ & 0.007 & $0.023^{* *}$ & $0.029 * * *$ & $.0170^{* *}$ \\
Pval of diff & 0.064 & 0.000 & 0.388 & 0.017 & 0.004 & 0.021 \\
N & 10437 & 10437 & 10437 & 10437 & 10437 & 10437 \\
Fp & 0.000 & 0.000 & 0.000 & 0.000 & 0.000 & 0.000 \\
R & 0.13 & 0.129 & 0.128 & 0.129 & 0.130 & 0.130 \\
Green-Toxic (S) & $0.024 *$ & $0.008^{* * *}$ & 0.005 & $0.024 * *$ & $0.030^{* * *}$ & $0.0160^{* *}$ \\
Pval of diff & 0.077 & 0.010 & 0.532 & 0.015 & 0.003 & 0.0369 \\
Green-Toxic (NC) & $0.028 * * *$ & -0.002 & 0.000 & $0.032^{* * *}$ & $0.053^{* * *}$ & $0.012^{* * *}$ \\
Pval of diff & 0.000 & 0.439 & 0.896 & 0.000 & 0.000 & 0.000 \\
\hline
\end{tabular}

\begin{tabular}{|c|c|c|c|c|c|c|}
\hline \multicolumn{7}{|c|}{ Panel B: Implied Long-term Growth by categories based on KLD strengths and concerns } \\
\hline Variable & Community & Diversity & Employee & Environment & Product & Overall \\
\hline Strength & $\begin{array}{l}0.006 \\
(1.35)\end{array}$ & $\begin{array}{l}-0.001 \\
(-0.28)\end{array}$ & $\begin{array}{l}-0.001 \\
(-0.55)\end{array}$ & $\begin{array}{l}0.002 \\
(0.64)\end{array}$ & $\begin{array}{l}0.019 * * * \\
(3.42)\end{array}$ & $\begin{array}{l}0.002^{* *} \\
(2.06)\end{array}$ \\
\hline Concern & $\begin{array}{l}-0.013^{* *} \\
(-1.99)\end{array}$ & $\begin{array}{l}-0.010 * * \\
(-2.05)\end{array}$ & $\begin{array}{l}-0.007 \\
(-1.19)\end{array}$ & $\begin{array}{l}-0.006^{* *} \\
(-2.32)\end{array}$ & $\begin{array}{l}-0.005 \\
(-1.31)\end{array}$ & $\begin{array}{l}-0.005^{* *} \\
(-2.1)\end{array}$ \\
\hline LOGass & $\begin{array}{l}-0.003 \\
(-1.26)\end{array}$ & $\begin{array}{l}-0.003 \\
(-1.03)\end{array}$ & $\begin{array}{l}-0.002 \\
(-0.74)\end{array}$ & $\begin{array}{l}-0.002 \\
(-0.7)\end{array}$ & $\begin{array}{l}-0.002 \\
(-0.91)\end{array}$ & $\begin{array}{l}-0.001 \\
(-0.48)\end{array}$ \\
\hline LTDTA & $\begin{array}{l}-0.054^{* * *} \\
(-6.17)\end{array}$ & $\begin{array}{l}-0.054^{* * *} \\
(-5.6)\end{array}$ & $\begin{array}{l}-0.055^{* * *} \\
(-5.75)\end{array}$ & $\begin{array}{l}-0.056^{* * *} \\
(-5.98)\end{array}$ & $\begin{array}{l}-0.054^{* * *} \\
(-5.77)\end{array}$ & $\begin{array}{l}-0.056 * * * \\
(-5.59)\end{array}$ \\
\hline RDPS & $\begin{array}{l}0.001 \\
(0.31)\end{array}$ & $\begin{array}{l}0.001 \\
(0.43)\end{array}$ & $\begin{array}{l}0.001 \\
(0.53)\end{array}$ & $\begin{array}{l}0.002 \\
(0.69)\end{array}$ & $\begin{array}{l}0.001 \\
(0.34)\end{array}$ & $\begin{array}{l}0.001 \\
(0.52)\end{array}$ \\
\hline Intercept & $\begin{array}{l}-0.037 \\
(-0.59)\end{array}$ & $\begin{array}{l}0.032 \\
(-0.49)\end{array}$ & $\begin{array}{l}-0.039 \\
(-0.62)\end{array}$ & $\begin{array}{l}-0.044 \\
(-0.69)\end{array}$ & $\begin{array}{l}-0.040 \\
(-0.62)\end{array}$ & $\begin{array}{l}-0.038 \\
(-0.59)\end{array}$ \\
\hline Industry Controls & yes & yes & yes & yes & yes & yes \\
\hline $\mathbf{N}$ & 10437 & 10437 & 10437 & 10437 & 10437 & 10437 \\
\hline $\mathrm{Fp}$ & 0.000 & 0.000 & 0.000 & 0.000 & 0.000 & 0.000 \\
\hline $\mathbf{R}^{2}$ & 0.1291 & 0.1284 & 0.1282 & 0.1281 & 0.1297 & 0.1311 \\
\hline
\end{tabular}

The table shows the differences in the implied growth parameter from equation (9) in the text by portfolios formed on the basis of strengths and concerns across CSR dimensions. In Panel A portfolios are formed on the basis of firms with only positive CSR scores in that dimension and no negative scores in that dimension ('Green'), firms with only negative CSR scores in that dimension and no positive scores in that dimension ('Toxic'), together with firms with no scores ('Neutral') and mixed scores ('Gray') in that dimension. In Panel A Green-Toxic (NC) shows the results of a t-test (without controls variables) for difference in the implied growth between 'Green' and 'Toxic' groups. Green-Toxic(S) shows the results where LOGsales is used as a control for firm size instead of LOGass. Green-Toxic(NC) shows the difference between portfolios of 'Green' and 'Toxic' stocks without any control variables. In Green-Toxic(NC), the difference in mean is computed using a ttest for difference in means. $F_{p}$ reports the $p$-value corresponding to the F-statistic and shows the overall significance of the regression model. In Panel B portfolios are formed on the basis of number of CSR strengths and concerns in that dimension. LTDTA is Leverage, measured as the ratio of Long-term Debt to Total Assets (LTDTA), LOGass is the natural log of Total Assets and RDPS is the Research and Development expenditure per share. t-statistics computed using cluster 
robust standard errors from the two-way cluster approach of Petersen (2009) are shown in parentheses. ${ }^{*}, * *$ and ${ }^{* * *}$ denote significance at the $10 \%, 5 \%$ and $1 \%$ percent level respectively. 
Table 8. Simultaneously derived implied growth and implied cost of equity capital estimates, based on Easton et al. (2002)

\begin{tabular}{|c|c|c|c|c|c|c|}
\hline \multicolumn{7}{|c|}{ Panel A- Implied Growth } \\
\hline Variable & Community & Diversity & Employee & Environment & Product & Overall \\
\hline Green & $\begin{array}{l}-0.025^{* * *} \\
(-10.07)\end{array}$ & $\begin{array}{l}0.010^{* * *} \\
(10.18)\end{array}$ & $\begin{array}{l}-0.002 \\
(-1.17)\end{array}$ & $\begin{array}{l}0.001 \\
(0.48)\end{array}$ & $\begin{array}{l}-0.014^{* * *} \\
(-4.24)\end{array}$ & $\begin{array}{l}0.004^{*} \\
(1.92)\end{array}$ \\
\hline Grey & $\begin{array}{l}0.033 \\
(1.03)\end{array}$ & $\begin{array}{l}0.002 \\
(0.40)\end{array}$ & $\begin{array}{l}-0.011^{* *} \\
(-2.37)\end{array}$ & $\begin{array}{l}-0.041^{* * *} \\
(-9.82)\end{array}$ & $\begin{array}{l}-0.005 \\
(-0.82)\end{array}$ & $\begin{array}{l}-0.006^{* * *} \\
(-3.49)\end{array}$ \\
\hline Toxic & $\begin{array}{l}-0.030 * * * \\
(-12.77)\end{array}$ & $\begin{array}{l}0.013^{* * *} \\
(10.02)\end{array}$ & $\begin{array}{l}-0.008 * * * \\
(-5.88)\end{array}$ & $\begin{array}{l}-0.036 * * * \\
(-17.21)\end{array}$ & $\begin{array}{l}-0.025^{* * *} \\
(-12.07)\end{array}$ & $\begin{array}{l}-0.004^{* *} \\
(-2.18)\end{array}$ \\
\hline LOGass & $\begin{array}{l}-0.001^{* *} \\
(-2.45)\end{array}$ & $\begin{array}{l}-0.000 \\
(-1.04)\end{array}$ & $\begin{array}{l}-0.001 * * * \\
(-3.29)\end{array}$ & $\begin{array}{l}-0.000 \\
(-0.77)\end{array}$ & $\begin{array}{l}-0.001 * * * \\
(-4.76)\end{array}$ & $\begin{array}{l}-0.001 * * * \\
(-4.54)\end{array}$ \\
\hline LTDTA & $\begin{array}{l}-0.015^{* * *} \\
(-2.77)\end{array}$ & $\begin{array}{l}-0.014^{* * *} \\
(-4.70)\end{array}$ & $\begin{array}{l}-0.022^{* * *} \\
(-7.28)\end{array}$ & $\begin{array}{l}-0.016 * * * \\
(-5.87)\end{array}$ & $\begin{array}{l}-0.019 * * * \\
(-7.63)\end{array}$ & $\begin{array}{l}-0.015^{* * *} \\
(-5.08)\end{array}$ \\
\hline RDPS & $\begin{array}{l}-0.000 \\
(-0.17)\end{array}$ & $\begin{array}{l}0.002^{*} \\
(1.67)\end{array}$ & $\begin{array}{l}0.002^{* *} \\
(2.09)\end{array}$ & $\begin{array}{l}0.002 \\
(1.32)\end{array}$ & $\begin{array}{l}0.001 \\
(0.63)\end{array}$ & $\begin{array}{l}0.001 \\
(1.12)\end{array}$ \\
\hline Intercept & $\begin{array}{l}0.092 * * * \\
(27.97)\end{array}$ & $\begin{array}{l}0.075^{* * *} \\
(29.54)\end{array}$ & $\begin{array}{l}0.092 * * * \\
(32.74)\end{array}$ & $\begin{array}{l}0.086^{* * *} \\
(40.88)\end{array}$ & $\begin{array}{l}0.092 * * * \\
(47.52)\end{array}$ & $\begin{array}{l}0.090 * * * \\
(33.06)\end{array}$ \\
\hline Industry Controls & yes & yes & yes & yes & yes & yes \\
\hline Green-Toxic & 0.005 & $-0.003 * *$ & $0.006 * * *$ & $0.037 * * *$ & $0.011 * * *$ & $0.008 * * *$ \\
\hline Pval of diff & 0.128 & 0.025 & 0.002 & 0.000 & 0.003 & 0.000 \\
\hline $\mathbf{N}$ & 12051 & 12134 & 12048 & 11687 & 11221 & 10669 \\
\hline $\mathrm{Fp}$ & 0.000 & 0.000 & 0.000 & 0.000 & 0.000 & 0.000 \\
\hline R-sq & 0.015 & 0.014 & 0.009 & 0.072 & 0.041 & 0.011 \\
\hline Green-Toxic (S) & 0.005 & $-0.004 * * *$ & $0.006 * * *$ & $0.037 * * *$ & $0.011^{* * *}$ & $0.008^{* * *}$ \\
\hline Pval of diff & 0.126 & 0.007 & 0.002 & 0.000 & 0.003 & 0.000 \\
\hline Green-Toxic (NC) & 0.006 & $-0.003 * *$ & $0.005^{* * *}$ & $0.038 * * *$ & $0.013^{* * *}$ & $0.008^{* * *}$ \\
\hline Pval of diff & 0.081 & 0.011 & 0.005 & 0.000 & 0.001 & 0.000 \\
\hline
\end{tabular}

\begin{tabular}{lllllll}
\hline Panel B. Implied Cost of Equity capital & & & & & \\
\hline Variable & Community & Diversity & Employee & Environment & Product & Overall \\
\hline Green & $-0.015^{* * *}$ & $0.009^{* * *}$ & 0.001 & $-0.007^{* * *}$ & $-0.012^{* * *}$ & 0.002 \\
& $(-9.39)$ & $(12.70)$ & $(0.88)$ & $(-4.25)$ & $(-5.84)$ & $(1.53)$ \\
Grey & 0.013 & $0.011^{* * *}$ & 0.000 & $-0.029^{* * *}$ & -0.011 & 0.000 \\
& $(0.81)$ & $(3.92)$ & $(0.08)$ & $(-8.72)$ & $(-1.57)$ & $(0.06)$ \\
Toxic & $-0.018^{* * *}$ & $0.014^{* * *}$ & 0.000 & $-0.023^{* * *}$ & $-0.011^{* * *}$ & $0.003^{* *}$ \\
& $(-12.21)$ & $(15.99)$ & $(0.59)$ & $(-17.02)$ & $(-8.20)$ & $(2.28)$ \\
LOGass & $-0.002^{* * *}$ & $-0.002^{* * *}$ & $-0.002^{* * *}$ & $-0.001 * * *$ & $-0.002^{* * *}$ & $-0.002^{* * *}$ \\
& $(-7.01)$ & $(-7.98)$ & $(-9.53)$ & $(-8.37)$ & $(-12.70)$ & $(-11.21)$ \\
LTDTA & $-0.012^{* * *}$ & $-0.011^{* * *}$ & $-0.016^{* * *}$ & $-0.010^{* * *}$ & $-0.015^{* * *}$ & $-0.013^{* * *}$ \\
& $(-4.24)$ & $(-5.30)$ & $(-7.54)$ & $(-5.12)$ & $(-7.98)$ & $(-6.43)$ \\
RDPS & 0.000 & 0.000 & 0.000 & $0.002^{* * *}$ & -0.000 & 0.000 \\
& $(0.19)$ & $(1.41)$ & $(1.02)$ & $(2.65)$ & $(-0.61)$ & $(0.91)$ \\
Intercept & $0.133^{* * *}$ & $0.123^{* * *}$ & $0.134 * * *$ & $0.131^{* * *}$ & $0.138^{* * *}$ & $0.133^{* * *}$ \\
& $(69.61)$ & $(72.04)$ & $(71.48)$ & $(96.18)$ & $(92.93)$ & $(72.76)$ \\
Industry Controls & yes & yes & yes & yes & yes & yes \\
Green-Toxic & 0.002 & $-0.005^{* * *}$ & 0.000 & $0.0156^{* * *}$ & -0.000 & -0.001 \\
Pval of diff & 0.271 & 0.000 & 0.7437 & 0.000 & 0.716 & 0.605 \\
$\mathbf{N}$ & 12053 & 12134 & 12054 & 11690 & 11228 & 10671 \\
Fp & 0.000 & 0.000 & 0.000 & 0.000 & 0.000 & 0.000 \\
R-sq & 0.022 & 0.036 & 0.012 & 0.075 & 0.042 & 0.020 \\
Green-Toxic (S) & 0.002 & $-0.007^{* * *}$ & -0.000 & $0.016^{* * *}$ & -0.000 & -0.002 \\
Pval of diff & 0.304 & 0.000 & 0.776 & 0.000 & 0.883 & 0.207 \\
Green-Toxic (NC) & 0.002 & $-0.008^{* * *}$ & -0.002 & $0.017^{* * *}$ & 0.001 & $-0.002 *$ \\
Pval of diff & 0.2241 & 0.0000 & 0.1585 & 0.0000 & 0.5341 & 0.0694 \\
\hline
\end{tabular}




\begin{tabular}{|c|c|c|c|c|c|c|}
\hline \multicolumn{7}{|c|}{ Panel C. R-G Differences } \\
\hline Variable & Community & Diversity & Employee & Environment & Product & Overall \\
\hline Green & $\begin{array}{l}0.010^{* * *} \\
(9.12)\end{array}$ & $\begin{array}{l}-0.001 * * * \\
(-3.34)\end{array}$ & $\begin{array}{l}0.002^{* * *} \\
(3.97)\end{array}$ & $\begin{array}{l}-0.008^{* * *} \\
(-7.01)\end{array}$ & $\begin{array}{l}0.001 \\
(0.98)\end{array}$ & $\begin{array}{l}-0.002^{* *} \\
(-2.20)\end{array}$ \\
\hline Grey & $\begin{array}{l}-0.017 \\
(-1.06)\end{array}$ & $\begin{array}{l}0.009 * * * \\
(4.96)\end{array}$ & $\begin{array}{l}0.012^{* * *} \\
(6.87)\end{array}$ & $\begin{array}{l}0.014^{* * * *} \\
(9.27)\end{array}$ & $\begin{array}{l}0.006^{* * *} \\
(2.73)\end{array}$ & $\begin{array}{l}0.006^{* * *} \\
(7.96)\end{array}$ \\
\hline Toxic & $\begin{array}{l}0.013^{* * *} \\
(11.01)\end{array}$ & $\begin{array}{l}0.000 \\
(1.60)\end{array}$ & $\begin{array}{l}0.008^{* * *} \\
(14.21)\end{array}$ & $\begin{array}{l}0.013^{* * *} \\
(13.15)\end{array}$ & $\begin{array}{l}0.015^{* * *} \\
(14.89)\end{array}$ & $\begin{array}{l}0.007^{* * *} \\
(8.42)\end{array}$ \\
\hline LOGass & $\begin{array}{l}-0.000 * * * \\
(-3.77)\end{array}$ & $\begin{array}{l}-0.001 * * * \\
(-10.80)\end{array}$ & $\begin{array}{l}-0.001 * * * \\
(-6.79)\end{array}$ & $\begin{array}{l}-0.001 * * * \\
(-10.58)\end{array}$ & $\begin{array}{l}-0.001 * * * \\
(-11.55)\end{array}$ & $\begin{array}{l}-0.001 * * * \\
(-7.98)\end{array}$ \\
\hline LTDTA & $\begin{array}{l}0.003 \\
(1.17)\end{array}$ & $\begin{array}{l}0.003^{* * *} \\
(2.78)\end{array}$ & $\begin{array}{l}0.006^{* * *} \\
(4.73)\end{array}$ & $\begin{array}{l}0.006^{* * *} \\
(5.23)\end{array}$ & $\begin{array}{l}0.005^{* * *} \\
(4.40)\end{array}$ & $\begin{array}{l}0.002^{*} \\
(1.91)\end{array}$ \\
\hline RDPS & $\begin{array}{l}0.000 \\
(0.51)\end{array}$ & $\begin{array}{l}-0.000^{*} \\
(-1.75)\end{array}$ & $\begin{array}{l}-0.001^{* *} \\
(-2.47)\end{array}$ & $\begin{array}{l}0.000 \\
(0.18)\end{array}$ & $\begin{array}{l}-0.000 \\
(-1.04)\end{array}$ & $\begin{array}{l}-0.000 \\
(-1.12)\end{array}$ \\
\hline Intercept & $\begin{array}{l}0.042^{* * *} \\
(26.32)\end{array}$ & $\begin{array}{l}0.048^{* * *} \\
(44.86)\end{array}$ & $\begin{array}{l}0.043^{* * *} \\
(33.83)\end{array}$ & $\begin{array}{l}0.046^{* * *} \\
(44.33)\end{array}$ & $\begin{array}{l}0.046^{* * *} \\
(53.24)\end{array}$ & $\begin{array}{l}0.043^{* * *} \\
(37.27)\end{array}$ \\
\hline Industry Controls & yes & yes & yes & yes & yes & yes \\
\hline Green-Toxic & $-0.003 *$ & $-0.002 * * *$ & $-0.006^{* * *}$ & $-0.021 * * *$ & $-0.013^{* * *}$ & $-0.009 * * *$ \\
\hline Pval of diff & 0.0814 & 0.000 & 0.000 & 0.000 & 0.000 & 0.000 \\
\hline $\mathbf{N}$ & 12051 & 12134 & 12048 & 11687 & 11221 & 10669 \\
\hline $\mathrm{Fp}$ & 0.000 & 0.000 & 0.000 & 0.000 & 0.000 & 0.000 \\
\hline R-sq & 0.010 & 0.020 & 0.028 & 0.060 & 0.047 & 0.032 \\
\hline Green-Toxic (S) & $-0.003 *$ & $-0.003 * * *$ & $-0.006 * * *$ & $-0.021 * * *$ & $-0.012 * * *$ & $-0.01 * * *$ \\
\hline Pval of diff & 0.0645 & 0.000 & 0.000 & 0.000 & 0.000 & 0.000 \\
\hline Green-Toxic (NC) & $-0.003^{*}$ & $-0.004 * * *$ & $-0.007 * * *$ & $-0.02 * * *$ & $-0.012 * * *$ & $-0.01 * * *$ \\
\hline Pval of diff & 0.0348 & 0.000 & 0.000 & 0.000 & 0.000 & 0.000 \\
\hline
\end{tabular}

The Table reports the result of solving the Easton et al. (2002) regression described in (10) for portfolios sorted on year, Fama-French 10 industry group, and portfolios formed on the basis of formed of firms with only positive CSR scores in that dimension and no negative scores in that dimension ('Green'), firms with only negative CSR scores in that dimension and no positive scores in that dimension ('Toxic'), together with firms with no scores ('Neutral') and mixed scores ('Gray') in that dimension. In the Panels Green-Toxic (NC) shows the results of a t-test (without controls variables) for difference in the implied growth between 'Green' and 'Toxic' groups. Green-Toxic(S) shows the results where LOGsales is used as a control for firm size instead of LOGass. Green-Toxic(NC) shows the difference between portfolios of 'Green' and 'Toxic' stocks without any control variables. In Green-Toxic(NC), the difference in mean is computed using a t-test for difference in means. $F_{p}$ reports the $p$-value corresponding to the F-statistic and shows the overall significance of the regression model. In Panel $B$ portfolios are formed on the basis of number of CSR strengths and concerns in that dimension. LTDTA is Leverage, measured as the ratio of Long-term Debt to Total Assets (LTDTA), LOGass is the natural log of Total Assets and RDPS is the Research and Development expenditure per share. t-statistics computed using cluster robust standard errors from the two-way cluster approach of Petersen (2009) are shown in parentheses. ${ }^{*}, * *$ and $* * *$ denote significance at the $10 \%, 5 \%$ and $1 \%$ percent level respectively. 


\section{Appendix A}

\begin{tabular}{|c|c|c|}
\hline Dimension & Strengths & Concerns \\
\hline \multirow[t]{8}{*}{ Community } & Generous giving & Investment Controversies \\
\hline & Innovative giving & Negative Economic Impact \\
\hline & Support for housing & Indigenous Peoples Relations \\
\hline & Support for education (added in 1994) & Tax Disputes \\
\hline & Indigenous peoples relations strength (2000-2002) & Other Concern \\
\hline & Non-U.S. charitable giving & \\
\hline & Volunteer programmes strength (added 2005) & \\
\hline & Other strength & \\
\hline \multirow[t]{8}{*}{ Diversity } & CEO & $\begin{array}{l}\text { Employee discrimination (renamed from } \\
\text { controversies }\end{array}$ \\
\hline & Promotion & 2007 Aug) \\
\hline & Board of directors & Non-representation \\
\hline & Family benefits & Other concern \\
\hline & Women/minority contracting & \\
\hline & Employment of the disabled & \\
\hline & Progressive gay/lesbian policies (added in 1995) & \\
\hline & Other strength & \\
\hline \multirow[t]{6}{*}{ Employee } & $\begin{array}{l}\text { Union relations strength } \\
\text { No layoff policy (through 1994) }\end{array}$ & $\begin{array}{l}\text { Union relations concern } \\
\text { Health and safety concern (renamed from } \\
\text { safety }\end{array}$ \\
\hline & Cash profit sharing & controversies in 2003) \\
\hline & Employee Involvement & Workforce reductions \\
\hline & Strong retirement benefits & Pension/benefits concern (added in 1992) \\
\hline & Health and safety strength (added in 2003) & Other concern \\
\hline & Other strength & \\
\hline \multirow[t]{7}{*}{ Environment } & Beneficial products and services & Hazardous waste \\
\hline & Pollution prevention & Regulatory problems \\
\hline & Recycling & Ozone depleting chemicals \\
\hline & Alternative fuels & Substantial emissions \\
\hline & Property, plant, and equipment (through 1995) & Agricultural chemicals \\
\hline & Management systems (added 2006) & Climate change (added in 1999) \\
\hline & Other strength & Other concern \\
\hline \multirow[t]{4}{*}{ Product } & Quality & Product safety \\
\hline & R\&D/innovation & Marketing/contracting controversy \\
\hline & Benefits to economically disadvantaged & Antitrust \\
\hline & Other strength & Other concern \\
\hline
\end{tabular}

